\title{
Bronisław Panek
}

\section{Synod Rzymski}

Prawo Kanoniczne : kwartalnik prawno-historyczny 5/1-2, 231-268

1962

Artykuł został zdigitalizowany i opracowany do udostępnienia w internecie przez Muzeum Historii Polski w ramach prac podejmowanych na rzecz zapewnienia otwartego, powszechnego i trwałego dostępu do polskiego dorobku naukowego i kulturalnego. Artykuł jest umieszczony w kolekcji cyfrowej bazhum.muzhp.pl, gromadzącej zawartość polskich czasopism humanistycznych i społecznych.

Tekst jest udostępniony do wykorzystania w ramach dozwolonego użytku. 


\section{SYNOD RZYMSKI}

Słusznie i niebezpodstawnie można nazwać Synod Rzymski synodem wzorcowym. Jesteśmy wprawdzie przyzwyczajeni spoglądając na Rzym widzieć tam przede wszystkim Papieża-Zastępcę Chrystusa na ziemi, Głowę widzialną Kościoła Katolickiego i nie wszyscy uświadamiają sobie, że każdorazowy Ojciec św. jest równocześnie biskupem-Ordynariuszem diecezji rzymskiej. Jeżeli zwykli śmiertelnicy w Kościele Katolickim mogą tego nie dostrzegać, to $z$ calą pewnością Ordynariusze całego świata katolickiego i ich Kurie Diecezjalne bacznie śledza posunięcia i prace tego Ordynariusza Ordynariuszy szukając tam słusznie wzoru i zachety do swoich przedsięwzięć.

Synodem Rzymskim interesują się wszyscy księża, bo wiedzą, że to co zostało powiedziane w Rzymie odbije się jakims echem we wszystkich Kuriach Diecezjalnych, a o duchowieństwie synod mówił dużo, choc nie zawsze nowe rzeczy.

Ustawodawstwem synodalnym winni się interesować nie tylko duchowni, ale i świeccy katolicy, choćby tylko $w$ myśl powiedzenia ,nostra res agitur", ale nie tylko dlatego. W naszych czasach tyle sie mówi o roli laikatu $w$ Kościele, że już żaden prawodawca kościeiny nie odważy się milczeniem pominąc glosów wydobywających się z ,katolickich dołów". Nie będzie więc bez pożytku zarówno dla duchownych jak i dla świeckich katolików polskich bliższe zapoznanie się z niektórymi uchwalami synodu rzymskiego i to tym bardziej, że sam tekst synodu nie jest jeszcze latwo dostępny dla wszystkich.

\section{Przygotowania i ugłoszenie Synodu}

Oäręcznym pismem swoim z dnia 16 stycznia 1960 r. Papiez Jan XXIII wyznaczył początek I Synodu Diecezji Rzymskiej na dzień 24 stycznia tegoż roku $\mathrm{w}$ bazylice Lateraneńskiej. Celem synodu miało być ożywienie wiary katolickiej w Wiecznym Mieście, pogłębienie moralności chrześcijańskiej oraz umocnienie $w$ karności duchownych i świeckich katolików i dostosowanie jej do współezesnych patrzeb. Synad został uprzednio dobrze przygotowany. Już bowiem 18 lutego 1959 roku Papiez ustanowil specjalną Komisję, która pod jego osobistym kie- 
rownictwem miała przygotować materiał do uchwał synodalnych. Następnie zostało utworzonych osiem podkomisji, które miały przygotować projekty tych uchwał, każda w swoim zakresie, w zależności jednak od komisji centraInej. Wyniki prac podkomisji zostały przesłane przebywającym w Rzymie kardynałom, kierownikom różnych wydziałów Kurii Rzymskiej, wyższym przełożonym zakonnym, proboszczom, przelożonym licznych kolegiów itp. Wszyscy oni mieli na piśmie złożyć swoje spostrzeżenia i dezyderaty.

Aby zaś ten wysiłek ludzki nie poszedł na marne zarządzil Papież powszechne modły zwłaszcza od 10 do 16 stycznia.

Synod zacząl się 24 stycznia $1960 \mathrm{r}$. w bazylice Lateraneńskiej, a zakończony został 27 stycznia w bazylice św. Piotra.

Następnie polecił Papieź opracować ostateczny tekst uchwał synodalnyck $\mathrm{z}$ uwzględnieniem tego wszystkiego co zastało powiedziane zarówno przeciw projektom ustaw, jak i tego co bylo $z$ nimi zgodne. Taki dokładnie przygotowany i w języku łacińskim wydany tekst uchwał synodalnych Papiez zatwierdził i promulgował Konstytucją apostolską ,Sollicitudo omnium Ecclesiarum” w dniu 29 czerwca $1960 \mathrm{r}$. $z$ tym, że mocy wiążącej nabierały one dopiero $z$ dniem 1 listopada $1960 \mathrm{r}$. Terenowo uchwały synodu rzymskiego obowiązują w całej diecezji Rzymskiej, w bazylice św. Piotra i w Państwie Watykańskim.

Uchwały Synodu rzymskiego podzielone sa na trzy księgi:

I. O osobach art. 19-220.

II. O duszpasterstwie art. 221-709.

III. O dobrach kościelnych art. $710-755$.

Te trzy księgi poprzedzone są przepisami ogólnymi art. 1-18.

\section{Zasady ogólne}

Papiez jako biskup rzymski i jedyny prawodawca na synodzie zniósł wszystkie ustawy diecezjalne niezgodne $z$ uchwałami tego synodu, nie naruszając jednak przywilejów i wyjątków uznanych przez prawo powszechne albo udzielonych przez Stolice Apostolską. Gdyby jednak $w$ tej materii zostały wprowadzone jakiekolwiek zmiany lub poprawki, to obowiązują one tylko $w$ diecezji rzymskiej.

We wszystkich wątpliwościach należy się zwracać na piśmie do ustanowionej przez Papieża Komisji, której wyjaśnienia zatwierdzone przez Papieża będą umieszczone w diecezjalnym czasopiśmie Rivista Diocesana. Od uchwał synodu rzymskiego $w$ poszczególnym wypadku może dyspensować Kardynał Wikariusz, zwolnienia ogólnego lub na stałe może udzielić tylko sam Papiez..

Charakterystycznym jest to, że moc wiążącą poszczególnych uchwał synodalnych trzeba rozpoznać z brzemienia ich samych, bo nie zawsze 
są one nakazami lub zakazami, ale, bardzo często podane są $\mathrm{w}$ formie zachęty i rady, wszystkie jednak należy przyjąć $z$ uległością.

Obowiązują one w granicach diecezji rzymskiej, a wiẹc zachowywać je mają:

1. wszyscy duchowni, którzy podlegają wiadzy Kardynała Wikariusza, także i ci, którzy mu podlegają $z$ racji zamieszkania stalego lub tymczasowego w Rzymie, a w poszczególnych wypadkach także i podróżni nawet $w$ przejeździe tylko bawiący w Rzymie.

2. wszyscy zakonnicy, nawet wyjęci $z$ pod władzy Ordynariusza, chyba, że co innego wyraźnie synod stanowi.

3. Wszyscy czlonkowie stowarzyszeń o życiu wspólnym oraz instytutów swieckich.

4. klerycy seminariów i ci wszyscy, którzy w jakimkolwiek charakterze prowadzą życie religijne $w$ instytutach i kolegiach kanonicznie erygowanych w Rzymie.

5. wierni należący do diecezji rzymskiej.

6. wszyscy urzędnicy Kurii rzymskiej, którzy na mocy przywileju są wyjęci $z$ pod jurysdykcji swoich ordynariuszy, oraz wszyscy biskupi i ordynariusze przebywający w Rzymie.

7. Wikariuszowi Kardynałowi podlegają także duchowni, zakonnicy i świeccy wierni obrządku wschodniego, przebywający w Rzymie. a tym samym zobowiazani są do zachowywania ustaw synoda!nych $z$ wyjątkiem przepisów liturgicznych.

Autentyczny tekst $w$ języku łacińskim albo zatwierdzone tłumaczenie ustaw synodalnych muszą posiadać wszyscy duchowni, wszystkie urzędy Stolicy Apostolskiej, jakiekolwiek zakłady szkolenia religijnego, kapituly, seminaria, kolegia, domy zakonne, szpitale o ile tam pracuja osoby zakonne, oddziały Akcji Katolickiej i innych organizacji o charakterze apostolskim.

\section{Rzymska Kuria Diecezjalna}

W drugim tytule przepisów ogólnych podane są zasady organizacji rzymskiej Kurii diecezjalnej. Do diecezji rzymskiej należy Wikariat miasta Rzymu, Państwo Watykańskie i bazylika św. Piotra. Kurię wikariatu miasta Rzymu stanowi Kardynał Wikariusz, jego zastępca i odpowiednie urzędy, zwłaszcza sekretariat i sąd.

Kardynal Wikariusz ma władzę zwyczajną zastępczą, którą ograniczyć może tylko sam papież i która nie wygasa Sede vacante; sprawuje on poza tym pełnię władzy kapłańskiej.

Taką samą władzę w zależności jednak od Kardynała Wikariusza sprawuje jego zastępca, mianowany przez papieża i piastujący gođność arcybiskupią. Do pomocy Kardynałowi Wikariuszowi sa przydani bi- 
skupi pomocniczy, a zakres ich wladzy zależy od Kardynała Wikariusza.

Od czasu do czasu dla sprawniejszego kierowania diecezją Kardynal Wikariusz ma zwoływać tych wszystkich swoich pomocników i urzędników na narady. On też ma wydać $z$ aprobátą papieską odpowiednie statuty określające zakres władzy i obowiązki poszczególnych urzędów. W państwie watykańskim jurysdykcję pełni Wikariusz Generalny mianowany przez papieża, a bazylika św. Piotra podlega zgodnie z tradycją Kardynałowi Archiprezbyterowi.

\section{KSIE G A PIERW S Z A}

\section{Sekcja pierwsza}

\section{O duchownych diecezji rzymskiej w ogólności Przynależność do diecezji rzymskiej}

Do duchownych diecezji rzymskiej zalicza się tego kto otrzymał tónsurę z polecenia Kardynała Wikariusza, albo został inkardynowany na podstawie wyraźnej i pisemnej jego zgody. Sam pobyt w Rzymie choćby $i$ bardzo dlugi $z$ racji studiów jakichkolwiek lub piastowanego urzędu wbrew przepisom kan. 114 nie stwarza tym samym ani nawet nie daje podstawy do ubiegania się o przynależność do diecezji rzymskiej.

Zachowuje swoją moc kanon 641 o duchownych zakonnych sekularyzowanych.

\section{Życie wewnętrzne duchownych}

Przez fakt przyjęcia święceń kapłańskich przestaje kapłan należeć do siebie samego lub do krewnych czy przyjaciól i musi pamiętać, że w służbie Bożej nie może szukać doczesnych korzyści, a gdyby się ubiegal o stanowiska kościelne dowodziłby tyiko swojej niezdatności do ich otrzymania. Aby utrzymać $w$ sobie nadprzyrodzonego ducha kapłan powinien pielęgnować nabożeństwo do Trójcy Przenajśw., do Najśw. Eucharystii, Dzieciątka Jezus, Chrystusa Ukrzyżowanego, Najśw. Serca Jezusowego, Przenajdroższej Krwi, Imienia Jezus, Ducha Świętego, Najśw. Maryi Panny, św. Józefa, św. Apostołów Piotra i Pawła itd. Punktem centralnym kapłańskiego dnia ma być Msza św., którą powinien kapłan odprawiać bez pośpiechu, głosem donośnym, zachowując wszystkie rubryki -- w normalnych warunkach nie powinien szybciej odprawiać jak 25 minut, poświęcając odpowiednią ilość czasu na przygotowanie się do Mszy św. i dziękczynienie po niej. 
W zakrystii niech panuje miìczenie, a gdy już trzeba coć powiedzieć to szeptem.

Z wielkim szacunkiem i ostrożnością należy się odnosić do szat, bielizny i naczyń liturgicznych.

Kapłan celebrujący $w$ Rzymie może odprawić wotywne Msze św. w I Czwartek „Iuravit”, w I Piątek „Cogitationes" i w I Sobote „Gaudens gaudebo" o Niepokalanym Poczęciu lub „Adeamus” o Niepokalanym Sercu N.M.P. - i wtedy zyskuje odpust zupełny, który niezależnie od Mszy św. może ofiarowac za zmarłych.

Aczkolwiek w prywatnym odmawianiu można mówić brewiarz w dowclnym czasie i miejiscu, to jednak radzi się, aby go odmawiać przed Najśw. Sakramentem.

Wszystkim duchownym przebywającym $\mathrm{z}$ jakiegokolwiek powodu w Rzymie nakazuje się (,praecipitur") codzienne rozmyślanie a ponad to zaleca się inne praktyki duchowne jak nawiedzanie Najśw. Sakramentu, różaniec itd. w różnych — przykładowo podanych — intencjach.

Kaplani świeccy i zakonni powinni mieć stałego spowiednika i często $u$ niego się spowiadać. Radzi się nazwisko spowiednika podać do wiadomości Wikariatu gdy chodzi o kaplanów diecezjalnych, a do Kurii prowincjonalnej gdy chodzi o kapłana zakonnego.

Synod zaleca bardzo lekturę Pisma św. i innych ksiąg religijnych zwłaszcza żywoty świętych w Rzymie niegdyś pracujących.

Kapłani diecezjalni są zobowiązani do pięciodniowych rekolekcji corocznie przez pierwszych pięć lat a potem przynajmniej co trzy lata. Odpowiedni dokument mają przesłac do Wikariatu. Zakonnicy pod tym względem zachowują własne przepisy.

Bardzo się zaleca miesięczne skupienie. Przypomina także synod i zaleca tradycyjne nabożeństwa i praktyki pobożne: nabożeństwo czteraziestogodzinne, stacje wielkopostne itp. Specjalnie upomina, by kaplani nie zapomnieli odwiedzić cmentarz $w$ dzień zaduszny lub w czasie nastepnego tygodnia.

Dia zapewnienia sobie duchownych korzyści kapłani powinni się zapisać do III zakonu, lub jakiegoś stowarzyszenia religijnego.

Kapłani chorujący powinni postarać się o zezwolenie na kaplice domowe lub odprawianie Mszy św. siedząco, a w przypadkach cięższych zapewnić sobie przez porozumienie się z proboszczem stałe uczestnictwo w Sakramentach sw. Wszyscy kapłani powinni pamiętać o chorych kolegach przychodząc in z pomocą duchową i materialną, o ile by tego zaszla potrzeba.

Kapłani będący $w$ karach kościelnych, choćby może i odpadli cd Kościoła, nigdy nie powinni wątpić w miłosierdzie Boże ani dobroć i ludzkość przełożonych kościelnych. Inni kapłani związani z nimi węzłami przyjaźni powinni w nich budzic i podtrzymywać tę ufność. 
Wobec tych wszystkich nieszczęśliwych trzeba stosować zasadę głoszona przez Piusa XI "Im mniej możemy mówić z ludźmi o Bogu, tym więcej rozmawiajmy z Bogiem o tych ludziach". Dlatego też w podobnych okolicznościach nie należy unikać przyjacielskiej z nimi rozmowy, nie odmawiać im pociechy $w$ strapieniu, ani też pomocy materialnej, gdyby jej potrzebowali. (Jakiez to inne i dalekie od tak uporczywie głoszonego przez tyle wieków ,anathema sit" i ,vitandus est”).

Kapłan powinien się starać i o swój zewnẹtrzny wygląd, unikając jednak wszelkiej przesady. W Rzymie na mocy zwyczaju obowiązuje sutanna, kołnierzyk, płaszcz lub peleryna i kapelusz, obowiązuje także tonsura.

Duchowni przebywający z młodzieża na obozach i koloniach w granicach Italii mają stale nosie sutannę, w podróżach zagranicznych lub wycieczkach górskich obowiązują lokalne zwyczaje.

Aczkolwiek duchowni mają prawo szukać sprawiedliwości w sądzie, to jednak lepiej jest przebaczać, a na każdorazowe wystąpienie w sądzie świeckim w jakimkolwiek charakterze trzeba mieć zezwolenie Kardynała Wikariusza lub Przelożonego zakonnego. Biskupi bawiący w Rzymie, Prałaci wyjęci i wszyscy Ordynariusze potrzebują w takim wypadku zezwolenia samego Papieża.

Wszyscy duchowni zarówno diecezjalni jak i zakonni oraz kościelne osoby moralne powinny przykładem świecić w zachowaniu ustaw paristwowych także i tych, które związane są z opłatami np.: czynsze, podatki, przepisy drogowe itp. Należy unikać w tym jakiejkolwiek nieuczciwości, a gdy wypadnie bronić swoich praw, trzeba wobec władzy swieckiej zachować się godnie i $z$ szacunkiem.

Wszyscy ci, którzy mają obowiązek zaopatrzyć się $w$ tekst synodu powinni także od promulgowania sunodu zaprenumerować diecezjalny periodyk „Rivista Diocesana".

Jak z jednej strony powinni duchowni wystrzegać się lektury takich pism, które mogą ich zarazić duchem świata tego, tak $\mathrm{z}$ drugiej strony winni przez lekturę odpowieđnich äzieł i czasopism pogłębiać swoją wiedzę teologiczna i duszpasterske sprawności. W czasopismach niezgodnych z zasadami katolickimi nie mogą umieszczać artykułów, ani tych pism popiẹrać.

W tym wszystkim co łączy się ze studiami wyższymi, czy to na uniwersytetach państwowych, czy w zakładach kościelnych, trzeba zachować specjalne przepisy - obecnie okólnik Sw. Kongregacji do spraw seminariów i studiów, wydany 1.11.1950 r. a skierowany do Ordynariuszy włoskich.

Przy wszelkich kontaktach z ludźmi świeckimi, czy to w zakładach pracy, czy w budynkach mieszkalnych, duchowni mają świecić przykładem, a przy wynagradzaniu za pracę stosować przepisy wydane przez synod. 


\section{Kaplan - duszpasterz}

Żaden kapłan nie może zapomnieć, że przede wszystkim jest duszpasterzem i dlatego niezależnie od wieku, narodowości, stanowiska itp. w przeciągu roku od ogloszenia sunodu musi się postarać o władzę do słuchania spowiedzi i głoszenia słowa Bożego. Dotyczy to wszystkich kaplanów, którzy przynajmniej jeđen rok zamierzają spędzić w Rzymie, a tym bardziej jeżeli dłużej mają pozostać. Wszyscy kapłani powinni chętnie $w$ miarę sił swoich i możliwości pomagać $w$ duszpasterstwie przez odprawianie Mszy św. w oznaczonym czasie, głoszenie słowa Bożego przy różnych okazjach, słuchanie spowiedzi, nauczanie religii, opieke nad chorymi itp.

\section{Pobyt w Rzymie}

Kapłani diecezjalni i zakonni, poza swoim domem zakonnym, przybywający do Rzymu w przeciągu trzech dni mają złożyć w Wikariacie Miasta pisemne zezwoienie wlasnego Ordynariusza na przebywanie poza diecezją.

$\mathrm{z}$ Wikariatu otrzymują pisemne zezwolenie na pobyt $\mathrm{w}$ Rzymie. Kapłan, który po upływie tygodnia od wyznaczonego terminu złośliwie pozostaje nadal w Rzymie, podlega ipso facto suspensie a divis, zastrzeżonej Kardynałowi Wikariuszowi.

Kardynał Wikariusz wyznaczy roztropnego kapłana, który otoczy opieką i czujnością wszystkich kapłanów przebywających na jakichkolwiek studiach w Rzymie, a mieszkających poza kolegiami,który też będzie dla nich urządzal skupienia, dyskusje, zachęcał i kierował ich do pomocy $w$ duszpasterstwie. W czasie ferii lub wakacji mogą oni wracać swobodnie do swoich diecezji, ale na wyjazd gdzie indziej muszá mieć odpowiednie zezwolenie swoich ordynariuszy.

Kapłani obejmujący $w$ Rzymie beneficjum rezydencjonalne lub inny urząd powinni zgłosić się u Kardynała Wikariusza i traktowaé go jako swego ordynariusza. Na wyjazdy trwające ponad dwa tygodnie musza mieć zezwolenie Kardynała Wikariusza lub swego ordynariusza, a na wyjazdy do krajów zamorskich zawsze zezwolenie Kongregacji Soborowej.

Pochwaly godni są kaplani diecezjalni, którzy przynajmniej raz $\mathrm{w}$ roku $\mathrm{w}$ duchu posłuszeństwa przedstawią się Kardynałowi Wikariuszowi. Bez jego zezwolenia pisemnego nie mogą kapłani opuszczać diecezji ponad dni 15. Klerycy mający zezwolenie na przebywanie we wlasnych domach lub poza kolegiami zawsze mają powiadomić swego proboszcza ile razy za zgodą przełożonych opuszczają Rzym na cżas dluższy od tygodnia . 
Kapłani diecezjalni i przybysze powinni okazywać sobie wiele miłości i życzliwości, a proboszcza otaczać szacunkiem i wspierać pomocą w duszpasterstwie.

\section{Odprawianie Mszy św.}

Wszyscy kapłani, chociażby mieli przywilej kaplicy prywatnej, w nieđzielę i święta mają odprawiać Mszę św. publicznie i w godzinach wygodnych dla poszczególnych grup wiernych pełniących i w niedziele swoje obowiązki.

We wszystkich kościołach i kaplicach mają być specjalne księgi, w których będą zapisywać się kapłani odprawiający tam Mszę św., a wykaz tych kaplanów ma być przekazywany raz $\mathrm{w}$ miesiącu do Wikariatu. Nie dotyczy to kapłanów przydzielonych do tych kościołów lub kaplic.

Biskupi zaś, Prałaci wyjęci i wszyscy Ordynariusze nie muszą być nigdzie zapisywani, a do ołtarza mogą być dopuszczeni na podstawie dokumentu stwierdzającego ich godność.

Wszyscy kapłani prawnie przebywający w Rzymie mają co trzy lata odnowić zezwolenie na odprawianie Mszy św. - wydawane przez Wikariat Miasta i przedłożyć je tam gdzie celebrują. Kapłanom zakonnym wystarcza zezwolenie ich przełożonych, ale dane na piśmie.

W kaplicach sióstr ani jeden raz nie można dopuścić kapłana do oltarza, jeżeli przedtem kapelan lub upoważniony kapłan nie sprawdził jego dokumentów.

\section{Władza do sluchania spowiedzi i gloszenia Slowa Bożego}

Wladzę do słuchania spowiedzi św. w całej diecezji rzymskiej daje Kardynał Wikariusz, jego zastępca lub Kuria. O ile prośba o jurysdykcję oraz jej udzielenie było pisemne, to obejmuje ono cała diecezje, chyba że dane bylo $\mathrm{z}$ ograniczeniem, a w miejscach wyjętych $\mathrm{z}$ pod jurysdykcji Kardynała Wikariusza trzeba uzyskać zgodę tamtejszego przełożonego.

W diecezji rzymskiej nie ma rezerwowanych cenzur ani grzechów poza wyjątkiem, gdy kapłan złośliwie przedłuża swój pobyt $\mathrm{w}$ Rzymie bez zezwolenia, oraz cenzurami ,ab homine" na mocy kanonu 2247 $\S \S 2$ i 3 .

Jurysdykcję otrzymuje się na dwa lata po złożeniu podania na piśmie i udanym egzaminie przed specjalną komisją. Od egzaminu zwolnieni są doktorzy prawa, teologii lub nauk biblijnych.

Wszyscy kapłani uczestnicy pielgrzymek lub zjazdów odbywających się $w$ Rzymie, mają na mocy uchwały synodalnej jurysdykcję do 
spowiadania we wszystkich kościołach i kaplicach ilekroć zachodzi tego potrzeba ze strony reszty uczestników. Wladzę tę otrzymują oni w takim samym zakresie, w jakim była im udzielona we własnych diecerjach.

Zakcnnicy i zakonnice oraz ci wszyscy, którzy razem z nimi mieszkają mogą się spowiadać u kapłana, który przychodzi do nich ze Mszą św. lub innym nabożeństwem byleby tylko miał jurysdykcję do spowiadania $i$ to, gdy chodzi o zakonnice, dla niewiast także. Może on wtedy spowiadać i nie mieszkających w domach zakonnych jeżeli podejda do Konfesjonału.

Wszyscy kapłani nawet pielgrzymi na terenie diecezji rzymskiej moga się spowiadać u jakiegokolwiek kapłana, byleby nie był on w karach kościelnych i gdyby nie miał jurysdykcji to otrzymuje ją z samego prawa, ale tyiko do tego poszczególnego wypadku i dlatego nie powinien słuchać tej spowiedzi $\mathrm{w}$ konfesjonale, by inni nie pođchodzili.

Wyżsi przełożeni zakonów kleryckich mogą swoim podwładnym przybywającym do Rzymu udzielić jurysdykcji w całej diecezji na osiem dni nie licząc dnia, w którym została udzielona, w granicach i zakresie takim samym jaką mieli we własnych diecezjach. To samo może Ordynariusz wojskowy i jego Wikariusz Generalny w stosunku do kapłanów sobie podwładnych. $Z$ tymi samymi ograniczeniami i tylko na własnym terenie może uczynić to proboszcz w stosunku do kapłanów przyjezdnych posiadających zezwolenie na pobyt w Rzymie i odprawianie Mszy św.

Biskupi zarówno rezydujący w Rzymie jak i nie, jeżeli otrzymali jurysdykcje od Kardynała Wikariusza - i to bez egzaminu - zatrzymują ją na zawsze. Natomiast Prałaci Rzymscy wyjęci, wszyscy Ordynariusze, penitencjarze czterech bazylik rzymskich, kanclerz, oficjał, egzaminatorzy; sędziowie i rektorzy seminariów i kolegiów otrzymują jurysdykcję także bez egzaminów na czas trwania ich urzędu.

Proboszczowie mają jurysdykcje w calej diecezji na czas trwania ich urzędu. Wszyscy posiadający poza Rzymem zwykłą władzę do słuchania spowiedzi mogą w Rzymie spowiadać nie tylko swoich poddanych, ale i obcych o ile o to poproszą.

Kapłan, który złożyl egzamin w Rzymie dla uzyskania jurysdykcji nie może być egzaminowany przez żadnego Ordynariusza, chyba tylko na mocy kanonu 877 \& 2 tzn. gdyby ten wątpił, że kapłan jeszcze jest zdatny do spcwiadania.

O władzę głoszenia słowa Bożego trzeba także składać podanie do Kardynała Wikariusza i pod tymi samymi warunkami jak przy jurysdykcji do spowiedzi. Zazwyczaj obydwie wladze są udzielane równocześnie tzn. władza do spowiadania zawiera w sobie także głoszenie słowa Bożego, w tych samych granicach. 


\section{Karność kościelna}

Z wielkim szacunkiem odnosić się winni kapłani nie tylko do papieża ale $i$ do całej Kurii Rzymskiej. Jeżeli ktoś pod tym względem był winny $\mathrm{i}$ upomniany nie poprawil się, to może być ukarany $\mathrm{i}$ wydalony z Rzymu.

Także prawowitej wladzy świeckiej trzeba okazywać należny szacunek i posłuszeństwo. Ustosunkowanie się kapłana do kobiet winno być nacechowane powagą i roztropnością. Nawet krewnych powinien kapłan usunąć ze swego mieszkania, o ile utraciliby dobrą sławę.

Niech kapłan nie przywiązuje się do bogactwa ani za życia, ani niech go nie zostawia po śmierci. Dobrze będzie pamiętać slowa $z$ testamentu Sw. Piusa X „ubogi się urodziłem, ubogi żyłem, ubogi chcę umierać".

Duchowny powinien się wystrzegać tego wszystkiego co trąci handlem i zyskiem, nie powinien zapisywać się do żadnych organizacji politycznych ani do stowarzyszeń czysto świeckich, choćby one miały dobre cele i słuszne założenia.

Jeżeli kapłan musi w zakresie swego urzędu pertraktować z władzą czy to kościelną czy świecką niech pamięta, że nigdy dobrego celu nie osiąga się złymi środkami np. kłamstwem lub naruszeniem praw cudzych.

W miejscowościach nadmorskich i kuracyjnych na terenie diecezji rzymskiej obowiązują specjalne przepisy, poza diecezją należy zachować przepisy miejscowego Ordynariusza.

Nie wolno duchownym kupować i prowadzić pojazdów mechanicznych bez zezwolenia Kardynała Wikariusza danego na piśmie, nie wolno też bez prawdziwej konieczności jeździć razem z kobietami, a zakonnicom $z$ mężczyznami.

Duchownym wszelkiego rodzaju nie wolno brać udziału w jakichkolwiek widowiskach publicznych nie zatwierdzonych przez Władzę Kościelną, a nawet i wtedy, gdy imprezy te są zależne i zatwierdzane przez Wladzę Kościelną, trzeba mieć na to specjalne zezwolenie $\mathrm{z}$ Wikariatu miasta. $\mathrm{z}$ radia i telewizji $\mathrm{w}$ domu trzeba korzystać roztropnie i $z$ umiarem.

Duchowny winny przekroczenia powyższych zakazów, o ile był tego świadom będzie obłożony karami,ferendae sententiae" według uznania Kardynała Wikariusza. Duchowny wyższych święceń choćby raz tylko był $w$ teatrze, kinie lub cyrku nie zaaprobowanym przez władzę kościelną podlega ipso facto suspensie ,a divis" nikomu nie zastrzeżonej. Gdyby tam poszedł ubrany po świecku, zwiększa swoją winę i surowiej ma być: ukarany, nawet wydaleniem z Rzymu na-stałe.

Przy nadawaniu jakichkolwiek beneficiów i urzędów w diecezji rzymskiej należy brać pod uwage ustosunkowanie się kapłana do 
zarządzeń synodalnych zwłaszcza dotyczących rekolekcji, słuchania spowiedzi, głoszenia słowa Bożego i wszelkiej pracy duszpasterskiej. Kapłan uchybiający w czymkolwiek pod tym wzgędem nie może być awansowany.

\section{Sekcja II}

\section{O poszczególnych duchownych \\ Kapituly}

Mają się przyczyniać do ubogacenia kultu Bożego, a ich członkowie świecić przykładem kapłańskich cnót nie uchylając się od gloszenia słowa Bożego i słuchania spowiedzi św. zwłaszcza gdy kapituła ma sobie powierzone duszpasterstwo.

\section{Proboszczowie}

Parafie są jakby zawiasami, na których opiera się i obraca caly duszpasterski wysilek diecezji. Aby parafia to zadanie wypełniła winien ją ożywić nadprzyrodzony duch jedności oparty na mocnej wierze, a wszystkie jej poczynania powinny się rodzić z miłości, która nagli do szukania zaginionych, a nie tylko zadawala się radością $z$ najwierniejszych. Do tych założeń nadprzyrodzonych trzeba dostosować metody i środki nowoczesnego apostołowania.

Proboszcz winien pamiętać, że przede wszystkim jest duszpasterzem i to w Rzymie, ku któremu zwracają się oczy całego świata. Mianowany przez papieźa, pomaga on Zastępcy Chrystusa $w$ wykonywaniu biskupiego urzędu.

Dla własnego pożytku i aby prace jego nie były bezowocne powinien proboszcz dobrze przemyśleć to co odnosi się do duszpasterstwa a zawarte jest $w$ papieskich pouczeniach, w prawie kanonicznym lub synodalnym.

Zanim obejmie urząd musi złożyć przepisowy egzamin, a już po otrzymaniu nominacji ma odprawić kilkudniowe rekolekcje. Powinien kierować się miłością i roztropnością w wykonywaniu swego urzędu, a w szczególności strzec się winien krytyki swoich poprzedników i nie wydawać zarządzeń całkowicie sprzecznych z dotąd obowiązującymi. Aby nie popełnił błędów wynikających z braku rozwagi i natychmiastowej reakcji, niech się stara poznać religijny i moralny poziom powierzonego sobie środowiska. Nie może pominąć tak bardzo pomocnego w taj dziedzinie środka, jakim jest kartoteka parafialna, ale też nịe może zapomnieć, że najwięcej zdziała przez osobisty kontakt z parafianami. 
Gdyby kartoteki parafialnej nie było, to zaprowadzi ją jak najrychlej zgodnie $z$ instrukcją Wikariatu Miasta i utrzyma ją $\mathrm{w}$ takim stanie, aby kyla pomoca $w$ duszpasterstwie.

Specjalną troską duszpasterską otoczy dzieci, biednych i chorych. Sam zaś umiłuje konfesjonał i tabernakulum, przed którym będzie mówił brewiarz, a o dom Boży tak się będzie starał, by mógł zgodnie z prawdą powiedzieć „Dilexi decorem domus tuae".

Wielka ilość i różnorodność parafian a równocześnie niewystarczająca ilość kapłanów, stawiaja proboszcza wobec wielu trudności i dlatego,aby uniknąc decyzji nagłych i nie przemyślanych, do końca paźdżernika ułoży on na piśmie wraz ze swymi współpracownikami plan pracy na rok następny. Realizując zaś ten plan będzie robil konieczne poprawki i notował spostrzeżenia godne uwagi.

Zgodnie $z$ uchwalami synodu zorganizuje nauczanie wiary dla dzieci, młodzieży i dorosłych, a gdzie to możliwe będzie czuwał nad religijną formacją dzieci w szkołach podstawowych i średnich. Ponieważ sam nie będzie mógł wszystkiemu podołać niech korzysta z rad i wskazań innych biorąc udział w zebraniach organizowanych w ramach calej diecezji.

Proboszcz ma prawo i obowiązek udzielać wiernym słusznie go o to proszącym Sakramentów św. - zachowując wydane $w$ tej materii przepisy Kodeksu Prawa Kanonicznego i Synodu i czuwając by to samo czynili jego wikariusze lub kaplani pomagajacy mu w duszpasterstwie. Czuwać ma bardzo nad tym także, aby wierni zwłaszcza w niedziel $\epsilon_{t}$ i swwięta mogli i uczestniczyli we Miszy św. we wczesnych godzinach, przyjmowali Sakramenta św. Niech im pozwoli oglądać swego proboszcza modlącego się w Kościele i zachęca slowem i przykładem do czynnego udziału we Mszy św.

Prcboszcz ma obowiązek dopilnować, aby zmarli parafianie mieli pełny pogrzeb katolicki a krewnym zmarłego okaże ojcowskie wspólczucie.

Proboszczowi zastrzeżone jest poświęcanie mieszkań w okresie wielkanocnym.

Chociaż nie jest opiekunem poszczególnych grup Akcji Katolickiej lub innych organizacji religijnych, to jednak ma czuwać proboszcz nad duchową formacją członków tychże organizacji, bo oni pomogą mu podnieść duchowo całą parafię.

W każdym miesiącu zwoła proboszcz radę parafialną, do której z urzędu wchodzą wszyscy przewodniczący parafialnych organizacji religijnych, aby omówic bieżące sprawy parafialne lub diecezjalne i sprawdzać urzeczywistnianie powziętych zamiarów. Aby ułatwić wiernym spowiedź wielkanocną urządzi proboszcz poza rekolekcjami ogólnymi nabożeństwa stanowe, a przynajmniej co 10 lat urządzi misje parafialne. 
Proboszcz nie może opuszczać parafii bez odpowiedniego zastępcy a na wyjazd dłuższy od jednego tygodnia musi mieć pisemne zezwolenie $z$ Wikariatu. Poza urlopem nie może opuszczać parafii $w$ dni świąteczne bez ważnej i niespodziewanej przyczyny.

Powinien uczestniczyć $w$ każdomiesięcznym skupieniu organizowanym dla proboszczów w Rzymie i corocznie odprawić rekolekcje.

W parafiach, które Kardynał Wikariusz uzna za odpowiednie do tego, proboszcz, jego wikariusze i inni kapłani winni prowadzić życie wspólne dla własnego poźytku i dobrego przykładu w oczach wiernych. Wtedy nie mogą wchodzic $w$ rachubę żadni krewni, chyba za wyraźnym zezwoleniem Kardynała Wikariusza.

Wikariuszy swoich, zwłaszcza mlodych, otoczy proboszcz ojcowska trosisa i milością pamiętając, że ma z nimi wspólne kaplaństwo i że oni są jego pomocnikami. Powinien nimi kierować, służyć radą i dobrym przykładem, nawet gdy korzysta ze swojej władzy niech sie okaże bardziej bratem i przyjacielem, niech omawia z nimi sprawy parafialne i zaprasza ich na radę parafialną. Gdy chodzi o wynagrodzenie wikariuszy, należy zachować postanowienia synodu $w$ tej materii.

Proboszcz ma prowadzic dokładny inwentarz rzeczy parafialnych a bardzo się radzi, by piså także kronikę.

Gdyby Kardynał Wikariusz zamierzał zmienić granice parafii, proboszcz może wyrazić swoje zdanie, podda się jednak jego decyzji.

W każdej parafii rzymskiej raz w roku zarządzi proboszcz nabożeństwo żałobne za zmarłego swego poprzednika $\mathrm{z}$ udziałem parafian i zach€̨ci ich do modlitwy. Gdyby proboszcz zdaniem Kardynała Wikariusza stal się niezdolny do sprawowania nadal powierzonego mu urzędu, powinien $z$ niego zrezygnować, ufając, że nie zostanie on bez opieki i środków do życia.

Proboszczowie miasta. Rzymu tworzą kolegium, którym kieruje Kardynał Wikariusz a na zebraniach ogólnych może przewodniczyć jego cielegat.

Parafie rzymskie polączone są $w$ prefektury, na czele których stoi proboszcz zwany prefektem. Jest on mianowany na 3 lata przez Kardynała Wikariusza, a przysługują mu prawa i obowiązki dziekana.

Prefekci tworzą Radę i wybierają $z$ pośród siebie jej prezesa i sekretarza zwyklą większością glosów, wybór ten musi być zatwierdzony przez Kardynala Wikariusza.

\section{Wikariusze parafialni}

Są oni mianowani i przenoszeni przez Kardynała Wikariusza zgodnie $z$ postanowieniami Kodeksu Prawa Kanonicznego. Po nominacji wikariusz powinien się przedstawić Kardynałowi Wikariuszowi i zaraz 
zgłosic się u nowego proboszcza, aby podjąć pracę. Wikariusze z racji przyjętego obowiązku powinni pomagać proboszczowi w pracy, pokonywać razem $z$ nim trudności, po bràtersku dzielić $z$ nim radości i bóle, brać udział w zebraniach przez niego organizowanych. Proboszcza niech traktują jako kierownika i ojca, kochają go i będą mu posłuszni. Od czasu do czasu referować będą proboszczowi wyniki swoich poczynań,napotykane przy tym truđaności, a jego rady i napomnienia chętnie przyjmą.

Wszyscy wikariusze muszą wziąc raz w miesiącu udział w zebraniach dla nich organizowanych przez Kárdynała Wikariusza, a także w kursach dla nich urządzanych.

Bez wiedzy proboszcza nie mogą pođejmować żadnych zobowiązań nawet duszpasterskich poza granicami parafii. Jeżeli uczą religii w szkole publicznej niech pamiętają, że jest to dopelnienie i uzupeinienie katechezy parafialnej, że mają okazję zetknąc się z młodzieżą, której może nie spotykają w życiu parafialnym.

Wikariuszowi przysługuje miesięczny urlop i $w$ porozumieniu z proboszczem może go wykorzystać naraz lub w dowolnych częściach.

\section{Rektorzy kościołów}

Mianowani są przez Kardynała Wikariusza zgodnie z przepisami Kodeksu Prawa Kanonicznego. Powinni pamiętać, że nie mogą występować $w$ roli proboszczów, ani umniejszać ich praw lub szkodzić pariafialnemu duszpasterstwu. $Z$ proboszczem powinien uzgodnić porządek nabożeństw jak najwygodniejszy dla wiernych. Każdy rektor za główny swój obowiązek powinien uważać pomaganie $w$ duszpasterstwie parafialnym. W porozumieniu z proboszczem starał się będzie rektor, aby w jego kościele nie brakowało ludziom słowa Bożego. Kościołem swoim zawsze będzie służył proboszczowi ile razy zechce on tam celebrować jakieś nabożeństwo. Powinien brać udział w zebraniach, które organizuje proboszcz dla uzgodnienia duszpasterskich poczynan. Ofiary ze zbiórek nakazanych przez Wikariat ma odsyłać do proboszcza, a nie wolno mu zbierać ofiar publiczrie i poza kościołem bez zezwolenia Wikariatu.

\section{Kapelani}

Kapelanów i przewodniczących różnych organizacji religijnych mianuje zgodnie $z$ przepisami Kodeksu Prawa Kanonicznego Kardynał Wikariusz. Obowiązkiem ich jest czuwać, aby członkowie tych stowarzyszeń pogłębiali swoją wiedzę religijną i świecili przykładem chrze- 
ścijaŕskiej miłości. Ochotnie powinni pomagać proboszczom i czuwać nad tym, aby czołnkowie ich organizacji brali udział w życiu parafialnym, a sami niech uczestniczą zawsze w zebraniach organizowanych przez proboszcza w sprawach duszpasterskich.

Znosząc ogólne zasady prawa powszechnego synod zezwala Kardynałowi Wikariuszowi na udzielanie kapelanom szpitali i podobnych zakłađów następujących uprawnień:

1. moga $w$ kaplicy posiadać chrzcielnice i chrzcic dzieci tam urodzone lub przebywające, zawiadamiając tylko proboszcza o dokonanym chrzcie.

2. mogą bierzmować pod warunkami i w granicach takich samych jak proboszcz.

3. moga spowiadaé i udzielać jurysdykcji w poszczególnym wypadku kapłanom aprobowanym przez jakiegokolwiek ordynariusza.

4. mogą udzielać chorym wiatyku św.

5. mogą załatwiać wszystkie sprawy związane z Sakramentem małżeństwa i błogosławic sam ślub, jeżeli jedna ze stron jest $w$ danym zakładzie, ale dla godziwości tegoż poza niebezpieczeństwem śmierci mają podać do Wikariatu na piśmie przyczyny dila których malżeństwo ma być zawarte w szpitalu.

6. moga udzielaé chorym namaszezenia.

7. moga odprawiać wszystkie ceremonie pogrzebowe zmarłym w zakładzie.

8. poza tym mogą poświęcać mieszkania w czasie wielkanocnym, poświęcać wodę chrzcielną, urządzać procesje itd.

Kapelani mają obowiązek prowadzić księi ochrzczonych, bierzmowanych i zmarłych, robić tam prawem przewidziane adnotacje i wydawać odpowiednie swiadectwa, gdy ktoś o nie poprosi.

Akta małżeństw zawartych w zakładzie należy w podwójnym egzemplarzu odesłać do miejscowego proboszcza, aby ten dopelnił formalności przewidzianych prawem kodeksowym, konkordatowym lub zarządzeniem Wikariatu. Kapelani szpitalni troskliwie czuwać winni nad chorymi i pomagać całej służbie zđrowia bacząc pilnie by jedni i drudzy zwłaszcza w okresie wielkiejnocy przystąpili do Sakramentów św. Powinien zachować lączność z proboszczem i informowaś: go o swoich poczynaniach, a chorych tak ustawiać by i w szpitalu uczestniczyli w życiu parafialnym ofiarowując np. swe cierpienia za parafię.

Kapelani internatów młodzieżowych mianowani przez Kardynała Wikariusza powinni się uważać za wikariuszy miejscowego proboszcza i troszczyć się o to, aby $w$ dni świąteczne była Msza św. z kazaniem, aby $w$ dogodnych godzinach była okazja do spowiedzi, by w okresie wielkanocnym wszyscy przyjęli komunię św., aby była dobrze prowadzona nauka religii, przygotowanie do I Komunii św. i do bierzmowa- 
nia. Z taktem i uprzejmością odnosić się będą do wychowawców i kierowników internatów a kapłańską troską otoczą także wszystkich tam pracujących.

Kapelani robotników i organizacji spolecznych mianowani są przez Kardynała Wikariusza jako wspólpracownicy proboszcza w tym wszystkim co się odnosi do życia religijno-moralnego w zakładach pracy i innych instytucjach użyteczności publicznej. Powinni świecić przykładem zwłaszcza bahaterskiej wstrzęmięźliwości. Ich głównym zadaniem jest troska o pogłębianie wiedzy religijnej, społecznej i życia moralnego u Iudzi pracy oraz zachęcanie ich do Sakramentów św. zwłaszcza w okresie wielkanocnym. Sami muszą ustawicznie pelnić rolę stróżów sprawiedliwości i pokoju. Robotników i urzędników powinni prowadzić umiejętnie do uczestrictwa w życiu parafialnym.

Kapelani więzienni rozumiejąc dobrze wielkość swego zadania niech budzą w skazanych wielką ufność ku Ojcu Niebieskiemu i zachęcają do chrześcijańskiego pogodzenia się z cierpieniem. Niech otoczą ich swą troską kapłańską i zapewnią wystarczającą ilość spowiedników choćby w każdym tygodniu.

\section{Asystêenci kościelni}

Czlonkowie Akcji Katolickiej lub innych organizacji mają sobie pzydzielonego przez Kardynała Wikariusza kapłana-dyrektora, doradce czy asystenta. Jego głównym zadaniem jest czuwać, aby członkowie tych organizacji byli stali we wmierze i legli władzy kościelnej, aby pogłębiali swe życie wewnętrzne i dokładnie zachowywali prawa kościelne.

Ma on brać udział w zebraniach, podając zawsze na nich coś aktualnego z zakresu życia religijnego. Powinien to robić proboszcz, może jednals wyręczyć się innym kapłanem wyznaczonym przez Kardynała Wikariusza.

Kapłan asystent powinien kierować wszystko i wszystkich do uczestnictwa w życiu parafialnym, do podporządkowania się wytycznym ustanowionym przez proboszcza. Niech się troszczy by nowych zdobywać członków, a także zachęcać ich do udziału w organizacjach diecezjalnych bez uszczerbku jednak dla życia parafialnego.

Kaplani asystenci stowarzyszeń organizowanych $w$ kolegiach tak powinni urabiać umysły członków, aby ci byli zdolni nieść pomoc organizacjom parafialnym.

Kardynal Wikariusz mianuje godnego kapłana, który będzie jego delegatem od spraw Akcji Katolickiej. 


\section{Czzęś í II}

\section{O Zakonnikach}

\section{Zakony męskie}

Zakonnicy, dobrowolnie zobowiązawszy się do życia doskonalszego, skrupulatnie winni zachowywać to co synod o nich stanowi. Wszystko co dotyczy życia duchownych $w$ ogólności odnosi się także i do nich. Jeżeli pełnią obowiązki proboszczów, wikariuszy, rektorów, kapelanów itp. - wszystkie przepisy wydane $w$ tej materii muszą $\mathrm{i}$ oni zachować, o ile wyraźnie nie jest coś innego postanowione.

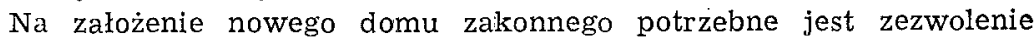
Kardynała Wikariusza z zachowaniem odpowiednich kanonów Kodeksu Prawa Kanonicznego. Zezwolenie udzielone na założenie nowego domu zawiera $w$ sobie $i$ drugie zezwclenie na prowadzenie dziel właściwych danemu zakonowi. Nie wolno bez specjalnego zezwolenia budować szkó lub innych zakładów odłączonych od domu zakonnego, ani przyjmować pensjonariuszy.

Przełożony powinien dążyć, by jak najwięcej swych współbraci-kapłanów skierować do duszpasterstwa. Dla uzgodnienia i usprawnienia tej działalności wyżsi przełożeni będą pamiętać, aby proboszcz zakonny byl zarazem w miare możności przełożonym domu.

Zakonnicy pracujący w duszpasterstwie we wszystkim zachowuja prawo diecezjalne i aby uniknąc zgorszenia ,jeđnomyślnie będą chwalić Boga".

Inaczej niż stanowi kanon $621 \S 1$ na zbieranie kwesty $w$ Rzymie, wszystkie zakony muszą mieć zezwolenie Wikariatu dane na piśmie. Nie wolno jest kwestować w miejseach publicznych - np. ulice, urzę$\mathrm{dy}$, jadłodajnie, biura itp.

Wszystkie udzielone zezwolenia są cofnięte, a nie przestrzegający tych przepisów będą karani.

Sposobem bycia i zachowania się powinni zakonnicy stać się ustawicznym wyrzutem i upomnieniem dla tych, którzy hołdują słabościom ludzkim i wygodzie życia.

\section{Zakony żeńskie}

Zakonnice niech pamiętają, że cale ich życie ma być apostolskie niezależnie od okoliczności czasu i miejsca. Aby wypełnily zadanie powolania swego winny modlitwá i pracą otoczyć wszystko dobro i piękno jakie Bóg-Stwórca ukrył w ludziach i w przyrodzie. 
Starając się o zalożenie nowego domu w Rzymie Przelożona generalna do podania dołączy zgode swoich radnych, listy polecajace od Ordynäriusza miejsca domu głównego, wykaz dzieł, które chcą prowadzić z zapewnieniem dostatecznej ilości sióstr, potrzebnych do tego środków, egzemplarz statutów oraz przysięgę, że siostry tam się umiejscowia, gdzie wskaże im Kardynał Wikariusz.

Bez zezwolenia Wikariusza nie wolno zmieniać ani wprowadzać nowych strojów zakonnych.

Na otwarcie kaplicy, przechowywanie Najśw. Sakramentu oraz ustawienie konfesjonału do słuchania spowiedzi św. trzeba otrzymać specjalne dekrety $\mathrm{z}$ Wikariatu.

W domach zakonnic nie można nawet na krótki czas przyjmować gości bez zezwolenia Wikariatu.

Zanim przełożona zabierze się do jakichkolwiek inwestycji musi zgłosić $\mathrm{w}$ Wikariacie kwotę, która rozporządza, plany zamierzonych prac, nazwiska wykonawców i kierujących tymi pracami.

Zakonnicom nie wolno podejmować nowych form apostolowania ani zaniedbywać dawnych bez zgody Wikariatu. Zakonnnice chętnie powinny służce pomocą $w$ pracach parafialnych, a gdyby napotkały na truđności niech je zglosza w Wikariacie.

Corocznie Przełożona ma składać sprawozdanie na piśmie ze stanu domu i działalności sióstr. Jak najrychlej winna się postarać o potrzebne władze, zezwolenia oraz pisemne potwierdzenie udzielonych ustnie.

Kapelana zakonnic, który $z$ reguły nie może być spowiednikiem, mianuje Kardynal Wikariusz. Kapelan nie może mieszać się ani do obowiązków poszczególnych sióstr, ani do ich życia wspólnego.

Władzy do spowiadania zakonnic i głoszenia im słowa Bożego udziela Wikariat tym kapłanom, którzy już uprzednio mieli jurysdykcję do spowiadania niewiast. Zwyczajny spowiednik nie może być równocześnie stałym kaznodzieją. Rekolekcjonista ma tym samym władzę do spowiadania zakonnic przez caly czas ich rekolekcji. Nie wypada, aby spowiednik zakonnic był kaznodzieją dla tych, którymi one opiekują się i na odwrót. Wszyscy spowiednicy zakonnic są mianowani na 3 lata i jeżeli nie ma wyraźnego zakazu, można ich kadencje przdlużyć na trzy lata następne. W międzyczasie przełożona może prosić o zmianę spowieỏnika, ale ta może nastąpić tylko przez złożenie rezygnacji przez spowiednika w Wikariacie lub przez nakaz z Wikariatu skierowany do owego spowiednika. Inne przepisy Kodeksu o spowiednikach pozostają w mocy. Ani spowiednik ani kaznodzieja nie mogą mieszać się do wewnętrznej lub zewnętrznej karności zakonnej.

Przynajmniej dwa miesiące przed przyjęciem do nowicjatu, przed pierwszą profesją i ślubami wieczystymi zgłosi przełożona kandydatki do Wikariatu.

Przy pierwszym egzaminie postulantka musi znać katechizm przy- 
najmniej na poziomie klasy $V$ szkoły podstawowej. W następnych musi znać cały katechizm przez św. Piusa $X$ nakazany oraz podstawowe wiadomości o życiu zakonnym a także uchwaly synodalne $w$ tej materij. Przepisy o klauzurze mają być skrupulatnie przestrzegane.

Zakonnice nie powinny wychodzić $\mathrm{z}$ domu pojedyńczo, to samo odnosi się do korzystania z pojazdów mechanicznych. W ostatnim wypadku powinny być odpowiednio ubrane.

Przy zbieraniu kwesty poza przepisami odnoszącymi się do zakonników winny pamiętać, aby zawsze we dwie kwestowaly i nigdy nie brały ze sobą dzieci. Na kwestę Przełożona niech posyła zakonnice najlepsze i nieco starsze.

Przy kupnie lub sprzedaży na większą sume powinny zawsze poradzić się biegłego $\mathrm{w}$ danej dziedzinie i otrzymać zezwolenie Wikariatu lub Stolicy Apostolskiej.

Przełożona zawsze powinna otaczać opieką swe dawne podwładne, ktọ́re z jakiegokolwiek powođu opuściły zgromadzenie.

Raz w roku Przelożone zbiorą się na zaproszenie Wikariatu dla wysluchania sprawozdań $z$ prac dokonanych lub zamierzonych przez poszczególne rodziny zakonne. Przed świętami Zesłania Ducha św. zakonnice wezmą udzial $w$ godzinie modlów o powolania kapłańskie. Przełcżona wyśle delegacje na nabożeństwo żałobne raz w roku urządzane za dusze zakonnic i ich podopiecznych zmarłych $w$ ubiegłym roku.

Podpis zakonnicy, która ma występować z ramienia swego instytutu, należy złożyć w Wikariacie.

\section{Instytuty świeckie itp.}

To wszystko co dotyczy zakonników i zakonnic stosuje się także do osób żyjących życiem wspólnym bez składania jeđnak ślubów publicznych. Instytuty świeckie są czymś nowym w kościele i gromadzą pragnących zachować rady ewangeliczne i zdobywać doskonałość chrześcijańską $w$ świecie. Członkowie tych instytutów powinni świecić przykładem świętości, apostolstwa i karności kościelnej.

$\mathrm{Część} \mathrm{III}$

\section{Katolicy świeccy}

Do świeckich $w$ pojęciu uchwał synodalnych zalicza się tych, którzy przyjęli chrzest św., a nie są duchownymi ani nie należą do zakonu. 
Są oni osobami w znaczeniu parwa kanonicznego i są podmiotami praw i obowiązków, których nie mogą się wyrzec. Niepowinni się oni zadawalniać życiem naturalnie pięknym, ale zabiegać o dobro nadprzyrodzone przez trwanie $w$ łasce uświęcające i dążenie do świę-tości, która ma być i ich udziałem także. Ponieważ obajwienie Boże podaje nie tylko prawdy religijne, ale i zasady moraine, dlatego nie można jednego od drugiego oddzielić nawet $w$ służbie ojczyzny.

Wszyscy katolicy maja obowiązek rozszerzania i obrony wiary świętej i gdyby to zaniedbywali pomagali by tym samym wrogom. Trzeba pamiętać i zrozumieć, że Kościól nie może lączyć się z żađnym stronnictwem politycznym lub z jakimś ugrupowaniem, gdyż sam jest ponad tym i wszyscy mają do niego prawo. Nie wolno też na rachunek Kościola zapisywać błędów poszczególnych katolików.

Troską otoczyć trzeba i ciało człowieka aczkolwiek bez bałwochwalczego kultu, gdyż ono wraz $z$ duszą jest świątynią Boga. Kobiety odrzucając falszywą emancypację niech będą wierne naturze i obowiązkom swoim. Porzadek przez Boga ustanowiony wymaga, abyśmy zachowali prawo moralne także $\mathrm{w}$ administrowaniu powierzonymi nam dobrami materialnymi jako też $w$ wykonywaniu swego zawodu lub urzędu.

Wiernych należy pouczyć:

1. o tzw. kwestii społecznej,

2. że dobra doczesne są przez Boga dane wszystkim i dzielone być winny ze sprawiedliwością i miłością,

3. że po zaspokojeniu własnych potrzeb, resztą należy się dzielić $z$ bliźnimi,

4. że trzeba się starać, aby i najbiedniejsi mogli zapracować na swoje potrzeby i zapewnić sobie byt na przyszłość,

5. że każdemu przysługuje prawo własności.

We wszelkich tranzakcjach wierni wystrzegać się winni oszustwa, nieuczciwości, wyzysku, łapówek itp.

Kościól ma prawo pouczać swych wiernych o ich obowiązkach obywatelskich np. przy głosowaniu. Katolicy pod ciężką odpowiedzialnością tak powinni korzystać $z$ środków lokomocji, aby nie narażać życia swojego ani cudzego. Wierni nie powinni bezwladnie ulegać postępowi technicznemu, ale kerować go ku chwale Bożej, dla podniesienia godności ludzkiej, dla ogólnego dobra i pokoju. 
KS I E G A DRUGA

\section{Oduszpasterstwie}

\section{Sekcja I}

\section{Nauczanie i jego formy}

W art. 46 Synod rzymski upomina, ,aby nigdy kapłan, niezależnie od swej godności i pozycji nie zapomniał, że jest duszpasterzem" i jakby chcąc być wiernym tej zasadzie sam synod poświęca problemom duszpasterskim więcej niż dwie trzecie swoich uchwał.

Przypomniawszy, że Kościół jest stróżem objawienia Bożego, że W Kościele nauczycielami z prawa Bożego są tylko biskupi zjednoczeni $z$ papieżem, że wszyscy inni kaplani pomagaja $i$ od nich zależa, domaga się synod od wszystkich wiernych zachowania gloszonych im zasad w życiu praktycznym, a już przykładem w tym świecić powinni Rzymianie, jako diecezjanie Zastępcy Chrystusa.

\section{Wyznanie wiary}

Pierwszym i zasadniczym obowiązkiem każdego chrześcijanina jest „być šwiadkiem prawdy w którą uwierzyl”. - (,Encyklika Jana XXIII "Princeps Pastorum), a świadectwo to ma dawać nie tylko słowem, ale i czynem. Znakiem zewnętrznym takiej postawy chrześcijańskiej będzie troska o misje, a więc modlitwa $w$ tej intencji i materialne wspomaganie dzieł misyjnych. Czynem świadczy katolik o swej wierze przez spoczynek niedzielny i uczestniczenie we Mszy św. Wyznaje on swą wiarę także i wtedy, gdy walczy ze słowem plugawym i obrażającym Boga. Rozmaite mogą być sposoby tej walki - od wywieszki upominającej umieszczonej $\mathrm{w}$ zakładzie pracy, przez braterskie upomnienie, aż do szukania pomocy władz świeckich np. w sądzie. Krzyż lub obraz religijny umieszczony na zaszczytnym miejscu $w$ mieszkaniu, a $w$ miare możliwości i $w$ zakładzie pracy jest także dowodem religijnej postawy ludzi mieszkających tam lub pracujących.

Świadeçtwem głębokiej wiary będzie też unikanie tego wszystkiego co by ją mogło ośmieszyć lub jej uwłaczać jak np. - uganianie się za cudownościami, przepowiedniami, objawieniami itp. $-Z$ tego te powodú należy unikać spirytyzmu, teozofii, hypnozy itd.

Aby uchronić czystą wiarę swoją katolicy zachowują wszystkie przepisy Kodeksu Prawa Kanonicznego ođnoszące się do współżycia z ka- 
tolikami. To samo dotyczy książek i czasopism traktujących o sprawach religijnych oraz zebrań i dyskusji na te tematy.

Rodzice zwrócą szczególną uwagę, aby w ich domu nie było nic zagrażającego czystości wiary.

Wszystkie kary przewidziane Kodeksem Prawa Kanonicznego i slużące do obrony wiary św. są nadal aktuaIne.

\section{Różne sposoby nauczania}

\section{Kaznodziejstwo}

Wielka troske wykazuje synod o gloszenie słowa Bożego. Kaznodzieja musi się odznaczać wiedzą głęboką, latwością wymowy i prawdziwą pobożnością. Czerpiąc stare prawdy i zasady z depozytu wiary musi je podać $w$ sposób odpowiedni dla dzisiejszych słuchaczy. Nie goniąc za popularnością i unikając sztuczności zwróci jednak uwage i na swoją postawę, głos i ruchy a zwłaszcza, by przykładem świętego życia wspierał gloszone przez siebie słowa.

Odpowiedzialność za głoszenie słowa Bożego spada na proboszcza $i$ to nie tylko $w$ kościele parafialnym ale we wszystkich kościolach na terenie parafii. On sam ma w każda niedzielę glosic swym wiernym aktualną homilię, poprzedzoną odczytaniem ewangelii względnie lekcji. od października do czerwca muszą być głoszone kazania katechizmowe dla dorosłych zgodnie $z$ planem diecezjalnym. Jeżeli kazanie głosi nie celebrujący, ale inny kapłan, to Mszę św. należy po ewangelii św. przerwać.

W dni świąteczne kazania mają być związane $z$ danym świętem. Poza tym nie może braknąć kazań adwentowych, wielkopostnych oraz odpustowych. Przynajmniej raz na 10 lat powinny być misje parafialne bardzo szczególowo obmyślane i dobrze przygotowane. Zaleca się bardzo wielkopostne rekolekcje oraz dni a nawet godziny skupienia.

Przemówienie z racji pogrzebu ma zawierać nie pochwałę zmarłego, ale wyrazy współczucia đla rodziny oraz zwrócenie uwagi uczestnikom na rzeczy ostateczne każdego człowieka.

Ogloszenia parafialne mają być jasne i krótkie a treść ich zawsze religijna.

\section{Nauczanie religii}

W duszpasterskiej pracy Kościola obok kaznodziejstwa postawić należy nauczanie prawd wiary św. Całą tą akcją kieruje referat diecezjalny dobierając sobie odpowiednich katechetów.

Dla przypomnienia świeckim katolikom ciążących na nich obowiązków w tej dziedzinie corocznie w drugą niedzielę listopada należy zorganizować „Dzień religijnego nauczania". Wszyscy kapłani diecezjalni i zakonni, członkowie zgromadzeń oraz instytutów świeckich a także 
i świeccy powinni pomagać proboszczowi, na którym ciąży odpowie-dzialność za nauczanie.

Rodzice, rodzice chrzestni i świadkowie od bierzmowania nie mogą być spokojni w sumieniu dokąd ich dzieci nie będą uczęszczaly na lekcje katechizmu, które powinny si ęodbywać przynajmniej w niedzielę.

Katecheci będą próbowali prawdy religijne zrozumiale podawać nawet i niezdolnym dzieciom korzystając z wszelkich dostępnych i w nauczaniu religii odpowiednich pomocy nowoczesnych np. - filmy, obrazy itd.

Nie można też zapomnieć o niedzielnej Miszy św. zarezerwowanej dzieciom, w czasie której biora one czynny udział i słuchają do nich dostosowanego kazania. Wszystko to odnosi się także i do miodzieży. Nauczanie religii powinno być ujęte w ramy podobnie jak w szkole a więc z podziałami na klasy, oddzialy itp. Proboszcz będzie prowadzil odpowiednie wykazy.

Pogłębianiu wiedzy religijnej służą i dlatego pochwały oraz zalecenia godne sa nowoczesne środki i metody: referaty i odczyty, kursy $i$ instytuty, radio, telewizja itp. Można $i$ trzeba $z$ tego korzystać i $\mathrm{W}$ miare możliwości zaprowadzać zgodnie z wytycznymi Wikariatu.

\section{Sekcja II}

\section{Chrzécijańskie wychowanie mlodzièy}

\section{Zasady chrześcijańskiego wychowania}

Prace wszystkich stowarzyszeń zajmujących się wychowaniem mìodzieży powinny być uzgodnione i kierowane przez odpowiedni Wydział Wikariatu. Celem wychowania jest „człowiek - chrześcijanin” i dlatego należy uwzględnić obydwa porządki i naturalny i nadprzyrodzony, które się wzajemnie uzupełniają. Roztropnie ograniczając zewnętrzne praktyki religijne należy zaprawić mlodzież do życia eucharystycznego, pobożności i czystości. U młodzieży trzeba budzić szlachetne poczucie godności $z$ przynależności do Kościoła i do diecezji rzymskiej oraz świadomość odpowiedzialności zá swe katolickie życie.

\section{$\mathrm{CZE} \mathrm{E}_{l} \mathrm{~S} \dot{\mathrm{C}}$ II}

\section{SaKramenta święte}

Duszpasterze powinni dążyć do wytworzenia przyzwyczajenia do Sakramentów, gdyż ono stwarza podstawy życia $z$ wiary. Niech nie braknie dokładnego i wszechstronnego pouczenia o Sakramentach św., aby wierni mogli je przyjmować $z$ większym pożytkiem duchowym. 
Kapłan udzielający Sakramentów św. nie może czynić tego pośpiesznie i lekceważąco, ale dokładnie pobożnie i zgodnie ze wszystkimi przepisami.

\section{Chrzest}

Naieży pouczyć wiernych o wielkości i skutkach chrztu św, o chrzcie w niebezpieczeństwie śmierci. $Z$ reguły chrzest powinien być we własnej parafii, gdyby odbył się gdzie indziej to należy zawiadomić własnego proboszcza. Rodziców chrzestnych należy dobierać odpowiednich, a jeżeli są nieznani szafarzowi chrztu św. to muszą przedłożyć świadectwo kwalifikacyjne od własnego proboszcza. Proboszczowie dopilnują, aby dzieciom dawano przynajmniej drugie imię chrześcijańskie.

Akta dokonanego chrztu należy prowadzić skrupulatnie i duplikaty posyłac do Wikariatu, dokonując wszystkich prawem przewidzianych adnotacji. Przy chrzcie dorosiych i chrzcie warunkowym obowiązują przepisy Kodeksu Prawa Kanonicznego.

Proboszczowie zachęcać będą wiernych do uroczystego obchodzenia rocznicy chrztu św.

\section{Eucharystia}

Rodzice powinni się troszcyć, aby dzieci ich $\mathrm{w}$ odpowiednim czasie przyjęly ten Sakrament. Nie powinno to być razem złączone z I Komunią św. Dzieci muszą być do tego odpowiednio przygotowane. Do świadków bierzmowania odnoszą się te same przepisy co i do rodziców chrzestnych.

Odpowiednie świadectwo wystawia biskup, albo na podstawie zostawionego przez niego dokumentu proboszcz.

\section{Bierzmowanie}

Centrem i ukoronowaniem życia religijnego jest Msza św., w której obecni powinni brać żywy udział. Poza tym co było już powiedziane o Mszy św, przy obowiązkach kapłańskich, Synod przypomina postanowienia Kodeksu w tej materii, a zwłaszcza prowadzenie ksiąg stypendiów mszalnych.

Zezwolenie na binacje lub trynację jest miejscowe a nie osobowe i dlatego ustaje, gdy zjawi się inny kapłan mogący odprawić Mszę św.

Nie tylko pouczyć ale i zachęcić należy do przyjmowania częstej, choć nie ze zwyczaju tylko, Komunii św. Wielka troskę wykazuje synod o Komunię św. wielkanocną, Komunię św. chorych i wczesną Komunię św. dzieci, ale przede wszystkim o pierwszą uroczystą Komunię 
św. dzieci. Ta ostatnia powinna się odbywać we własnej parafii a dzieci muszą być należycie przygotowane.

Powinna być ona bardzo uroczysta, ale bez świeckich, a tym bardziej gorszących akcentów.

Należy też potem nie tylko zachęcać dzieci do częstszej spowiedzi i komunii św. ale też im to ułatwić.

\section{Pokuta}

Spowiednik jest szafarzem sprawiedliwości i miłosierdzia Bożego, jest lekarzem i nauczycielem, ale przede wszystkim ojcem. Musi mieć wszechstronną wiedzę, ale też nie może mu brakować milości i roztropncsci.

* Spowiedź należy ulatwić zapewniając spowiednika w każdej chwili, a przynajmniej w oznaczonych godzinach, i od czasu do czasu zapraszać zupełnie obcych kapłanów. W celu ułatwienia też starszym, spowiedź dzieci urządzać $w$ innych godzinach, a mężczyzn spowiadać przed kobietami.

W samej spowiedzi kapłan będzie slużyl pomocą zwlaszcza przy obudzeniu żalu. Obowiązek spowiedzi wielkanocnej ciąży na dzieciach, które doszly do używania rozumu, a odpowiedzialność za ich zaniedbania spada na rodziców.

Należy też wiernych pouczyć o odpustach tak cząstkowych jak i zupelnych oraz ,toties quoties".

Wszystkie oltarze w Rzymie w których przechowuje się Najśw. Sakrament są uprzywilejowane. Proboszczowie otrzymują wiadzę poświęcenia znakiem krzyża św. w pewnych wypadkach.

\section{Ostatnie namaszczenie}

Należy tak pouczyć wiernych, aby nie sądzili, że ostatnie namaszczenie jest zapowiedzią śmierci i nie czekali z przyjęciem tego Sakramentu na ostatnią chwile. Mają do niego prawo także dzieci skoro przysaly do używania rozumu, chociaż nie przyjęły jeszcze I Komuniî św. W wypadkach wątpliwych i po nagłej śmierci należy udzielić namaszczenia $z$ warunkowym rozgrzeszeniem.

\section{Ka p $¥$ a ńn $\mathbf{t}$ wo}

\section{Powolanie}

$\mathrm{Z}$ wielką troską powinien kaplan wyszukiwać powolania i pielęgnować je i umacniać. Dziękując ustawicznie za łaskę swego powołania niech kapłan uważa sobie za najmilszy obowiązek wychowanie swego 
następcy w kaplaństwie. Aby się to stało powinien on świecić przykładem swojego kapłańskiego życia, często mówić o tych sprawach do ludzi oraz modlić się wiele i innych do modltwy w tych intencjach zachęcać, a zwlaszcza chorych i dzieci.

Pole do popisu maja tu nie tylko proboszczowie, ale i prefekci, katecheci, wychowawcy, rodzice itd.

Jak nie można kusząco namawiać nikogo, tak też nikt nie powinien hamować innych na drodze powołania.

Dobrze należy zbadać kandydata do seminarium a gdy ma ukończoną odpowiednią szkole nie wstrzymywać go $z$ racji młodego jeszcze wieku. Ostrożniej należy przyjmować zgłaszających się już po ukończonych innych studiach zwłaszcza gdy są to powołania opóźnione.

W każdej parafii powinno być zorganizowane przy pomocy świeckich dzieło powołań kapłańskich oraz urządzany „Dzień seminaryjny” niezależnie od diecezjalnego, który zawsze jest w Zielone Swiątki. W obchodach takiego dnia powinni brać udzial w miarę możliwości alumni $z$ seminarium.

Prcboszczowie należytą opieką otoczą alumnów w czasie ich pobytu $\mathrm{w}$ domu.

\section{Seminaria}

Kandydaci do kapłaństwa powinni się zgłaszać do Niższego i Wyższego Seminarium Rzymskiego a mogą té̇ być kierowani do innych wyższych uczelni. Zdobywając odpowiednią wiedzę i urabiając swoje charaktery mają się przygotować do czekających ich zadań, tak, aby im mogli sprostać w dzisiejszej rzeczywistości. Dlatego też rektorzy winni czuwać, aby przygotowanie seminaryjne nie było zupełnie oderwane od życia wspólczesnych ludzi.

Rektorzy ulatwią proboszczom wykorzystanie kleryków do niedzielnego nauczania dzieci prawd wiary.

Zarząd seminarium należy do rektora $i$ od niego wszyscy są zależni. Ojciec duchowny nie może się mieszać $w$ wewnętrzne rządy w seminarium a wszystko co dotyczy ćwiczeń pobożnych uzgadnia z rektorem. Nie może braknąć klerykom spowiedników, a już z reguły powinien przynajmniej jeden spowiadać w czasie rannych ćwiczeń.

\section{Święcenia}

Do święceń mogą być dopuszczeni kandydaci dopiero wtedy, kiedy dadzą dowody zdobytej wiedzy i wewnętrznego urobienia nie lekceważąc i fizycznego zdrowia. Rektorzy będą czuwać, aby przepisy Wikariatu o egzaminach były zachowane. Przez pięć lat po święceniach zdaje kapłan przewidziane egzaminy. 


\section{Malżeństwo}

Należy odpowiednio pouczać wiernych o naturze, godności i dobrach małżeństwa piętnując równocześnie bięđną opinię jakoby małżeństwo było czymś wznioślejszym od stanu dziewictwa.

Katolicy wszyscy, a zwłaszcza będący na stanowiskach, bronić będą nierozerwalności małżeństwa przeciw wszelkim teoriom rozwodowym.

Głównym celem małżeństwa jest zrodzenie i wychowanie dzieci i wszystiko inne temu ma być podporządkowane. Upominać należy wiernych, że onanizm małżeński, sztuczne zapładnianie, zamierzona sterylizacja są złym same przez się. Podając odpowiednie pouczenie należy się strzec jakiejś przesadnej seksuologii życia małżeńskiego.

IVałżeństwa powinny się kojarzyć i odbywać z wielką roztropnością, chrześcijańską czystością i milością. Zostawiając pełną swobodę wyboru rodzice zachęcą dzieci, aby do małżeństwa odpowiednio się przygctowywały.

Katolicy zobowiązani są $w$ sumieniu i to pod wielką odpowiedzialnością do zawierania małżeństw tylko kościelnych.

Zamierzający pobrać się powinni przynajmniej na dwa miesiące wcześniej zglosić się do swego probaszcza, który powie im jakie potrzebne będą dokumenty i da materiał do przerobienia na egzamin z katechizmu. W oznaczonym czasie proboszcz wybada każdego z nich czy mā wystarczającą wiedzę o małżeństwie, o obowiązkach małżeńskich, o wychowaniu dzieci itp. Proboszcz potraktuje to nie tylko jako egzamin $w$ ścisłym znaczeniu, ale jako okazję do uzupełnienia brakujących im wiadomości, potraktuje to jako zapoczątkowanie swego duszpasterstwa rodzinnego $w$ tym nowym małżeństwie.

Proboszcz ma się posłużyć drukami wydanymi przez Wikariat i zachować przez niego wydane normy postępowania przy zawieraniu małżeŕstw.

Dla uniknięcia trudności należy ostrzec nowożeńców, aby nie ustalali terminu ślubu zanim Wikariat nie da swego zezwolenia. Proboszcz ma odradzać, a gdy zajdą słuszne przyczyny odnieść się do Wikariatu - w wypadku małżeństwa niepełnoletnich, albo takich, którzy nie mogą zaraz razem zamieszkać, lub nie chcą dopełnić formalności prawa cywilnego. O zezwoleniu na małżeństwo udzielonym małoletnim należy powiađomić rodziców, o ile nie zachodzą wyjątkowe okoliczności.

Oprócz kościelnych zapowiedzi gloszonych zgodnie $z$ kan. 1025 powinny być zapowiedzi świeckie i gdy zachodzi potrzeba dyspensy zainteresowani mają się starać o nią u urzędnika państwowego.

W przygotowywaniu małżeństwa trzeba unikać jakiegokolwiek pośpiechli a milosierdzie $i$ milość $w$ tym wypadku mogą się okazać szkodiiwe dla samych nowożeńców. Na skrócenie drogi wyznaczonej przez prawo kościelne i konkordatowe zezwolić może tylko Wikariat. 
Zgodnie ze zwyczajem panującym w Rzymie wikariusze parafialni otrzymują od Wikariatu ogólną delegacjẹ do asystowania przy małżeństwach. Slub winien się odbyć w parafii narzeczonej albo dla słusznego powod̉u w parafii narzeczonego. Jeżeli ma być jeszcze gdzie indziej muszą nowożeńcy otrzymać na to zezwolenie i własnemu proboszczowi zapłacić ustaloną kwotę. Wszystkie formalności zarówno przed jak i po ślubie załatwia proboszcz narzeczonej i do niego należy kierować wszystkie dokumenty, a więc i ewentualne „Nihil obstat” uzyskane z Wikariatu, on też troszczy się o dokonanie odpowiednich adnotacji.

Śluby powinny się odbywać raczej nie $w$ święta nakazane, aby nie przeszkadzać $w$ liturgicznych czynnościach i o ile to możliwe razem ze mszą św. Jeżeli proboszcz uważalby za niewskazane uroczyste błogosławienie małżenstwa zlączone ze Mszą św. to i tak ślub niech się rano odbędzie, w godzinach mniejszego nasilenia ludzi w kościele.

Obrzędy ślubne mają. się odbywać zgodnie $z$ rytualem rzymskim i zaraz następuje odczytanie odpowiednich paragrafów prawa świeckiego. Same obrzędy ślubne winny być ladnie dopełnione. Nowożeńcy i goście odpowiednio ubrani zachowają się pobożnie, a po zakończeniu wyjdą z kościoła milcząco unikając wszystkiego tego, co nie przystoi miejscu świętemu.

Przy zawieraniu malżeństw mieszanych i postawionych na równi z nimi nie wolno urządzać w kościele żadnych ceremonii zgodnie $\mathrm{z}$ kanonem $1102 \S 2$.

Akt zawartego małżeństwa przed podpisaniem powinien być przeczytany w kościele lub kaplicy. Proboszcz niech pamięta aby wręczyć nowożeńcom „Książeczkę rodzinną”, w której już sam powinien wypełnić odpowiednie rubryki.

Gdyby zaszła potrzeba uprawnienia potomstwa, trzeba wypełnić odpowiedni formularz zgodnie $z$ zarządzeniami Wikariatu. Wszystkie dokumenty związane $\mathrm{z}$ zawarciem małzeństwa $\mathrm{w}$ miesiącu trzeba przesłać do Wikariatu.

zyjacych $w$ związkach nieprawych proboszcz winien upominać, wyjaśnić im dlaczego są pozbawieni Sakramentów św., pomóc do zmiany życia, ponadto zachęcić do ochrzczenia i chrześcijańskiego wychowania dzieci.

\section{Sakramentalia}

Należy pouczyć wiernych, aby $\mathrm{z}$ wiarą korzystali $\mathrm{z}$ sakramentaliów bez jakiegoś cienia zabobonu. W dopełnianiu sakramentaliów kapłan zachowa przepisy Rytuału a zanim cokolwiek poświęci wytlumaczy to najpierw ludziom, aby świadomie uczestniczyli w tych obrzędach.

W niedzielę przed główną Mszą św. ma być poświęcenie ludzi wodą święconą. 
Poświęcenie domów $\mathrm{w}$ czasie wielkanocnym jest zastrzeżone proboszczowi lub jego wikariuszom. Proboszcz powinien dokładnie ustalić trasę i wykorzystać tę okazję do zbadania moralnego położenia rodzin, religijnego wychowania dzieci i nawiązania kontaktu $\mathrm{z}$ chorymi. Ominąc należy $W$ czasie tego poświęcenia domy, w których są pornograficzne obrazy, gdzie mieszkają sekciarze, publiczni grzesznicy, albo walczący $z$ religią. W ostatnim wypadku jeżeli rodzina cała jest katolic$\mathrm{ka}$ to poświęcenia można dokonać.

Nie można poświęcać sztandarów ani domów organizacji świeckich nie zatwierdzonych przez Kościół. Sztandarów zaś należących do organizacji Kościolowi wrogich lub mających zakazane insignia nie można w ogóle dopuścić do Kościoła.

Obrzędów pogrzebowych można dopełnić tylko wtedy gdy pozwalaja na to rubryki.

W święta uroczyste $w$ ogóle niedopuszczalne jest dzwonienie na pogrzeb. Przy obrzędach pogrzebowych należy unikać przesađy w kwiatach, wieńcach itp. Do katafalku nie można użyć rzeczy $z$ oltarza np. lichtarze.

Jeżeli odprawia się Msza św., to modlitwy przy katafalku ,absolutio" ma odmówić celebrans, a nie kapłan odprowadzający zwłoki.

W bazylikach patriarchalnych corocznie ma być nabożeństwo żałobne $\mathrm{w}$ rocznicę śmierci ostatniego papieża. Proboszczowie obowiązkowo wezmą udział w takim nabożeństwie w bazylice lateraneńskiej.

\section{CZESC III}

\section{Kult Boży i liturgia}

Głównym zadaniem człowieka jest składanie Bogu należnej Mu czci. Prawdziwy i jedyny kult godny Boga ustanowil Jezus Chrystus skladając siebie $w$ ofierze za zbawienie świata. Ten kult Boży wraz ze swym założycielem trwa i żyje w Kościele Katolickim.

Wszyscy wydawcy książek liturgicznych muszą zachować przepisy wydane w tej sprawie przez Św. Kongregację Obrzędów.

Swiątynię jako dom Boży należy godnym otoczyć szacunkiem. Mężczyźni powinni tu przychodzić odpowiednio ubrani a kobiety przywdziá́c szaty zgodne $z$ chrześcijańską obyczajowością.

Zwiedzanie kościołów zabytkowych może mieć miejsce tylko poza Mszą św. a więc w. dzień powszedni po godz. 10 a w święta po godz. 15-tej, zawsze z należytym uszanowaniem. 


\section{Kult Najisw. Sakramentu}

Tabernakulum, w którym przechowuje się Najśw. Sakrament winno być nieruchome, z trwałego materialu, odpowiednio ozdobione i zasłonięte konopeum. Klucz od tabernakulum powinien być zawsze u kapłana lub kogoś innego upoważnionego i odpowiedzialnego, a nie może nigdy zostawać na ołtarzu. Na tabernakulum nie może być ani tronu do wystawienia, ani relikwiarza, ani kwiatów. Wieczna lampka, tylko $\mathrm{z}$ oliwą lub woskiem, nie może być złączona $\mathrm{z}$ ołtarzem. Pochwały godzien jest zwyczaj rozdzielania Komunii św. w czasie Mszy św., ale nie można rozdawać Hostii konsekrowanych w czasie Mszy św. przed Komunią Kapłańską.

W kościołach parafialnych oraz innych, ale nie $w$ kaplicach pó1publicznych, które nie byly uroczyście poświęcane, można $\mathrm{w}$ niedzielę i święta nakazane urządzać publiczną adorację $w$ monstrancji, o ile tylko jest odpowiednia ilość wiernych. Wtedy powinno się palić 20 świec woskowych, pođczas wystawienia prywatnego tzn. w puszce tych świec fowinno być sześć.

W czasie uroczystego wystawienia monstrancja powinna być umieszczona na tronie $\mathrm{i}$ w miarę możliwości między dwoma świecznikami, natomiast do błogosławieństwa eucharystycznego można monstrancję umieścič na ołtarzu.

Liturgiczne błogosławieństwo eucharystyczne składa się ze śpiewu Tantum ergo, Versetu i modlitwy oraz samego blogosławieństwa. Wszystko co jest przed tym lub potem, nigdy między wymienionymi czynnościami, uznać trzeba za akty czystej pobożności tylko. Modlitwy przed lub po błogosławieństwie nie powinny być długie i tylko z zatwierdzonych przez Kościól.

Czterdziestogodzinne nabożeństwo w Rzymie ma być bez przerwy nawet na błogosławieństwo nie wolno zdjąc monstrancji - a więc i przez noc, z przewidzianymi przez rubryki IMszami św., a proboszczowie lub rektorzy mają czuwać, aby nie brakło nigdy odpowiedniej liczby adorujących.

Dla uczezenia pamiątki ustanowienia Najśw. Sakramentu w każdy czwartek $w$ czasie wieczornego nabażeństwa przed benedykcją można śpiewać caly hymn „Pange lingua gloriosi”. Popierać trzeba i rozwijać Kult Serca Bożego, Przenajświętszej Krwi Jezusowej i Imienia Jezus.

\section{Kult Matki Bożej i Swiętych}

Kapłani zatroszczą się, aby rozwijał się i pogłębiał Kult Matki Bożej przez dogmatyczno-moralne powiązanie z jej świętami, przez odmawia- 
nie różańca, nabożeństwa majowe i październikowe, oddanie się Matce Bożej i inne praktyki pobożne razem $z$ pochwaly godnym zwyczajem budowenia maryjnych kapliczek.

Rzymianie powinni specjalnie czcić świętych Apostołów Piotra i Pawla oraz patronów swoich parafii. Swięta patronów lub tytułu kościoła można obchodzić $w$ niedziele uprzednią lub następną i to poprzedzane nowenną lub przynajmniej triduum.

Powinny być dokładnie zachowane przepisy o relikwiach świętych. Ile razy relikwie drzewa Krzyża św. były wystawione do publicznej adoracji lub procesji zawsze na końcu trzeba nimi udzielić wiernym błogoslawieństwa.

$\mathrm{Na}$ ołtarzu poza głównym obrazem nie może być żadnych innych malowideì i podobieństw, chyba, że są bardzo stare i artystyczne, ale $\mathrm{i}$ w tym wyapdku nie mogą zasłaniać obrazu głównego. To samo odnosię się do umieszczania różnych obrazów na ścianach Kościoła.

Swiece wotywne wierni mają składać rektorowi kościoła, a ten uwzględni ich życzenia.

\section{Specjalne akty kultu}

Bez zezwolenia Wikariatu nie wolns wprowadzać nowych nabożeństw ani procesji na zewnątrz. W święto Bożego Ciała jest jedyna procesja w Rzymie, w której mają wziąć udział wszyscy duchowni i orgarizacje męskie ze sztandarami, organizacje żeńskie stoją po bokach trasy procesji. W nąstępną niedzielę mogą podobną procesję urządzać parafie zgodnie z przepisami Wikariatu.

Pielgrzymki powinny mieć charakter religijny, zawsze z kapłanem -ojcem duchownym. Pielgrzymki dalsze do sanktuariów narodowych Iub zagranicznych organizuje Wikariat. Zachować trzeba i urządzać procesje w Kościołach stacyjnych, oraz rocznice papieskie.

\section{Życie liturgiczne}

Liturgia jest to publiczny kult Mistycznego Ciała Jezusa Chrystusa i dokonuje się $w$ imieniu Kościoła, przez osoby do tego upowaźnione i w sposób przez Kościól przepisany. Jeżeli choć jednego z tych przymiotów brak, to nie ma wtedy kultu liturgicznego, a są tylko praktylki pobożne - nabożeństwo. Te ostatnie nie maga być mieszane z kultem liturgicznym i zawsze tekst i sposób ich odprawiania powinien być zatwierdzony. 
Kapłani pouczą i zachęcą wiernych, aby brali udział w życiu liturgicznym, a przede wszystkim: w parafialnym kościele powinni przyjmować Sakrament chrztu św., bierzmowania i małżeństwa, a taizże Komunię św., tu powinni uczestniczyć we Mszy św. w niedzielę i święta nakazane.

To uczestnictwo najlepiej dokonuje się przez Mszę św. recytowaną. Wiernych należy pouczać przez odpowiednie prelekcje nawet międzyparafialne, zwłaszcza przed więlkszymi uroczystościami.

Jeżeli dopuszczalne są obrzędy grupowe to należy je wyżej cenić i uroczyściej urządzać niż pojedyncze np. chrzest kilkorga dzieci naraz.

Należy podtrzymać, a nawet i wznowić śpiewanie nieszporów.

\section{O ministrantach}

W każdej parafii powinno być koło ministrantów otoczonych wielką troską duszpasterską proboszcza lub innego zaufanego kapłana, aby nigdy nie brakło usługujących do Mszy św., aby pogłębić pobożność chłopców, budzić powołania i mieć kandydatów na kantorów i lektorów. Należy ich wyszkolić $w$ pełnieniu funkcji $w$ czasie rozmaltych nabożeństw, pogłębić ich pobożność, zaprawić do ukochania stanu łaski.

$\mathrm{W}$ trosce o powołania kapłańskie trzeba razem $\mathrm{z}$ nimi modlić się o to, a rodzące sie powolanie otoczyć opieką i pielęgnować.

W przerwach ministranci nie powinni być $w$ zakrystii $i$ nigdy nie wolno ich wynagradzać pieniężnie, ale gorliwość zaznaczać punktami.

\section{Muzyka i śpiew religijny}

Nie wolno pomijać i śpiewów przewidzianych $w$ liturgii. We Mszach św. śpiewanych nie można opuszczać ani skracać części zmiennych. Jeżeli niema odpowiednich śpiewaków to należy je śpiewać na sposỏb psalmów lub recytowac. W czasie czynności liturgicznych nie może być śpiewów w językach narodowych. W czasie Mszy św. cichej organ musi milczeć:

1. od introitu do Credo

2. podczas prefacji

3. od Pater noster do Agnus Dei

4. na Domine non sum dignus - wiernych

5. w czasie Communio, Postcommunio i na blogosławieństwo.

Gdzie się da powinny być śpiewane nieszpory po gregoriańsku, ale bez uszczerbku dla ogólnego śpiewu wiernych.

Zakazane są w kościele wszelkie instrumenty automatyczne i wszel- 
kie nagrania wykluczające artystyczny wysilek człowieka, a gdy niema odpowiedniego muzyka, to lepiej żeby wtedy nie było żadnej gry.

W czasie adwentu, Wielkiego Postu, suchych dni i mszy żalobnych organu używa się tylko do podtrzymania śpiewu.

Pożąđaną jest rzeczą, aby we wszystkich Kościołach był chór męski lub mieszany lub nawet czysto żeński.

W seminariach i innych zakładach Kościołowi podległych troskliwie należy pielęgnować muzykę kościelną i śpiew gregoriański i polifonicz ny. Pcżądaną jest w Rzymie szkoła dla organistów i dyrygentów chórów parafialnych, do której należy kierować odpowiednich kandydatów i pomóc im materialnie.

Kardynał Wikariusz mianuje specjalną Komisję, której zadaniem będzie: troszczyć się o muzykę kościelną i czuwać nad szkolą organistów i kantorów, zatwierdzać nowe utwory muzyki religijnej, zatwierdzać nowe organy lub remonty starych, czuwać nad poprawnością śpiewów liturgicznych i usuwać zwyczaje niezgodne $z$ przepisami liturgicznymi.

Specjalną opieką należy otoczyć śpiew gregoriański i stosować go w miarę możności przynajmniej w większe uroczystości kościelne. Zwłaszcza odnosi się to do seminariów, domów zakonnych itd.

W bazylikach i większych kościołach należy popierać śpiew polifoniczny, mający w Rzymie bogate tradycje, byleby tylko miał odpowiednich dyrygentów i śpiewaków. Nie wolno śpiewać falsetem, te partie powinni wykonać chłopcy.

Spiew ludowy powinien być zgodny $z$ ogólnymi zasadami i dopuszczalny jest w czasie Mszy św. czytanych, w czasie nabożeństw i procesji.

\section{Naczynia i szaty liturgiczne}

Naczyń świętych dotykać mogą kaplani, albo ci, którzy mają nad nimi pieczę.

Kielich powinien mieć takie cechy:

1. czarę srebrną i przynajmniej wewnątrz złoconą,

2. nie za mały, chyba, że do mszy polowych,

3. niewywrotny,

4. czara nie za głęboka i nie za szeroka,

5. nóżke między czarą i podstawą łatwą do uchwycenia,

6. kez ornamentów nieodpowiednich.

Kielich traci konsekrację przez znieważenie, publiczną sprzedaż, uszkodzenie istotne np. przedziurawienie, złamanie nóżki itp.

Wypada aby puszka była również srebrna i wewnątrz złocona, ma być poświęcona i okryta sukienką. Monstrancja też winna być złocona lub posrebrzana i nigdy nie przechowywana $w$ tabernakulum, hostie zaś przechowuje się $w$ kustodii. Naczyńka na oleje św. powinny być 
z metalu lecz wewnątrz mogą być szklane. Powinny być poświęcone i przechowywane w kościele, a tylko oleje św. do chorych mogą być na plebanii byleby $w$ odpowiednim miejscu:

Krzyż na oltarzu powinien. być w miarę możności wartościowy, proporcjonalny do lichtarzy. Zdjąć go można tylko w czasie publicznej adoracji Najśw. Sakramentu. Może być zastąpiony przez obraz Ukrzyżowanego umieszczony $w$ ołtarzu. Nie wolno umieszczać obrazów obrażających religijne uczucia wiernych.

Relikwiarzy nie można uźywać do ozdoby, a umieszczenie figur lub podobizn świętych na oltarzu jak najbardziej ograniczyć.

Pożądane jest, aby przynajmniej ołtarz z Najśw. Sakramentem był ubrany świeżymi kwiatami. Niedozwolone są kwiaty sztuczne lub ustawianie doniczek z zielenią na ołtarzu. Te ostatnie dopuszczalne są $\mathrm{W}$ prezbyterium. Na głównym ołtarzu powinno byé 6 proporcjonalnych lichtarzy, na oltarzach bocznych wystarcza 4 a nawet 2. Paschał powinien być cały woskowy a podtrzymujący go świecznik w miare możności z kamienia.

Oltarz wielkoczwartkowy $w$ ciemnicy ma byé oczyszczony $z$ jakichkolwiek symboli przypominających męke lub pogrzeb P. Jezusa, ma przypominać fakt ustanowienia Najśw. Sakramentu.

Szaty kapłańskie powinny być jedwabne i długie $w$ tradycyjnych liturgicznych kolorach. Alby z szerokimi koronkami, jako niezgodne z tradycją liturgiczną, są w ogóle niedopuszczalne.

Bursy od karporałów nie wolno używać do zbierania ofiar. W każơym kościele powinien być inwentarz szat liturgicznych.

\section{Miejsca i czasy święte}

Budowę nowego kościoła trzeba zacząć od uroczystego położenia kamienia węgielnego. Miejsca kultu muszą być poświęcane lub konsekrowane. Tylko za zezwoleniem Wikariatu Rzymu można celebrować w miejscach przeznaczonych dla celów świeckich lub pod gołym niebem.

Przy budowie nowych kościolów trzeba mieć na względzie odrazu dom parafialny $\mathrm{z}$ ođpowiednimi salami do katechizacji, zebrań itp., obok dużego ołtarza winna być chrzcielnica. Troską i czcią należy otoczyć front kościoła, aby ułatwiał oderwanie się od rzeczy świeckich i pomagał do skupienia.

$Z$ kościoła nie może być wejścia do żadnych sal lub widowni a zgielk panujący w tych miejscach nie może zakłócić ciszy kościoła. Rzeźba i malarstwo w kościele ma powiększać chwałę Bożą i pogłębiać pobożność wiernych, dlatego musi być latwe i proste, pełne zmysłu religijnego, a w niczym nie obrażające uczuć wiernych.

Klucz od kościoła powinien być u proboszcza lub jego zaufanego mającego pieczę nad kościołem. Gdy kościól jest otwarty, co jest pożądane jak najdłużej, powinien być strzeżony. 
W kościele, kaplicy lub wejściu do nich nie wolno sprzedawać dewocjonalii.

Pieniądze zlożone do skarbonek należy użyć zgodnie z ich przeznaczeniem. Pożądana jest skarbonka na ofiary na Miszę św. zbiorowe za zmarłych, ilość Mszy św. trzeba ustalić zgodnie z taksą diecezjalną.

W obrębie kościola nie wolno umieszczać ogłoszeń świeckich. Ogłoszenia dotyczące życia religijnego w parafii powinny być na specjalnych tablicach. Kropielnice winny być czyste i stosowne. Ambona tak ma być ulokowana, aby wierni nie musieli odwracac się od glównego ołtarza, można używać mikrofonów. Po ołtarzu i tabernakulum najważniejszym miejscem $w$ kościele jest chrzcielnica. Dlatego powinna być czysta i ladnà, ozdobiona motywami chrztu św. Oleje św., sól, świece, ręczniki powinny być przechowywane $w$ specjalnej i blisko umiejscowionej szafie.

Prezbiterium jest zarezerwowane dla duchownych i tylko w czasie ślubu mogą tam być nowożeńcy i świadkowie.

Droga krzyżowa jest bardzo zalecana i dlatego powinno być przynajmniej 14 krzyżyków drewnianych, a w większych kościołach pożądane są obrazy widoczne i czytelne $\mathrm{z}$ odpowiednimi napisami, zharmonizowane $z$ architekturą kościoła. W czasie uroczystości kościelnych może być dopuszczony jeden fotograf, tak jednak ma robić zdjęcia, aby nie przeszkadzał ani księdzu ani ludziom.

Światło ulatwiające spełnianie świętych obrzędów powinno być ukryte, a na ołtarzu nie może być świec elektrycznych lub ozdobnych żarówek przed tronem i wokól obrazów.

W miarę potrzeby można używać megafonów w Kościele, ale nie na zewnątrz bez zezwolenia Wikariatu. Można też w czasie procesji używat wzmacniacza do kierowania śpiewem.

Bez zezwolenia Wikariatu nie wolno $\mathrm{w}$ kościele wyświetlać filmów, urządzać audycji muzycznych, korzystać z epidiaskopu lub radia i telewizji.

Dzwony należycie poświęcone lub konsekrowane mogą być poruszane napędem elektrycznym zgodnie z przepisami danymi z Wikariatu - co do czâsu i jakości dzwonienia. Pochwały godny jest zwyczaj dzwonienia na modlitwy za zmarłych, po „Anioł Pański” oraz w piątek o godz. 15 dla przypomnienia śmierci Para Jezusa.

Oltarz jako obraz Chrystusa jest centrem kościol.a a więc powinien być pięknie i godnie urządzony. Zwłaszcza duży ołtarz powinien mieć menzę odpowiednio dużą i $w$ miarę możności oddalony od ściany, aby go można było obejść; między nim a ścianą nie powinno być żadnej nastawy. Oltarze przenośne (boczne) rzadko winny być używane i nigdy celebrujący przy nich nie powinien być odwrócony od Najśw. Sakramentu. Nie należy teź pomnażać ich liczby bez potrzeby. 
Eawe dla celebransa $i$ asysty ma być jednolita na jednostopniowym podwyższeniu z pełnym oparciem i nie może być zastąpiona krzesłami. Proboszczowie zachęcą wiernych, aby nawiedzali sławne arcybazyliki rzymskie sanktuaria maryjne oraz inne kościoły zwłaszcza poświęcone męczennikom.

Grohy powinny być zdobione symbolami wiary i nadziei a cmentarze otoczone należytą czcią i nawiedzane zwlaszcza przez oktawę dnia zaduszrego i cały listopad. Wiernym należy przypominać, że dobre uczynki więcej pomogą zmarłym niż piękne grobowce.

\section{Czasy święte}

Adwent należy wykorzystać na przygotowanie wiernych do Bożego Narodzenia, a dni suche do modlitwy o powołania kapłańskie. Szczególnie uroczyście należy odprawiać nowennę przed Bożym Narodzeniem i to oddzielnie dla dzieci i oddzielnie dla starszych.

Wielki Post jest czasem przeznaczonym na głębsze zastanowienie się i poprawę życia przez modlitwę i umartwienie. Złagodzenie przepisów postnych wierni powinni wyrównać osobistą pokutą i umartwieniem. Powinnỉ też uczestniczyć $w$ nabożeństwach stacyjnych, $w$ piątki w Drodze Krzyżowej oraz w szczególny sposób przeżyć ceremonie Wielkiego Tygodnia.

Uroczyście także obchodzić trzeba nowennę przed zesłaniem Ducha Ŝwiętego, aby przygotować wiernych na "Dzień powołań kapłańskich".

W dzień zaduszny. lub $\mathrm{w}$ dni następne proboszczowie powinni urządzać nabożeństwa $z$ katafalkiem za zmarłych parafian.

\section{CZES $\bar{C}$ IV}

\section{o apostolskiej pomoey świeckich \\ Obowiązek apostolstwa swieckich}

Obowiązek apostolstwa świeckich wynika z miłości względem Boga pragnącego zbawić wszystkich ludzi, z milości bliźniego, bo zbawienie jest jego najwyższym dobrem, z nauki o Mistycznym Ciele Chrystusa.

Dla świeckich dwa rodzaje apostolstwa są $w$ szczególny sposób dostępne a mianowicie: modlitwa i cierpienie. Nie powinni chrześcijanie zasklepiać się $w$ sobie nawet gdyby dążyli do świętości własnej, ale włączyć się do apostolskiej działalności Kościoła.

\section{Akcja dobroczynna}

Jest ona nie tylko obowiązkiem społecznym i środkiem uświęcenia osobistego, ale także wspaniałym świadectwem chrześcijańskiego życia. 
W bliźnim potrzebującym trzeba widzieć samego Chrystusa. Do kierowania tą akcją dobrze będzie wykorzystać siostry lub członków Instytutów Swieckich. Dyryguje i koordynuje tę calą działalność Wikariat przez odpowiedni Wydział. W szpitalach i więzieniach akcją dobroczynną kierują kapelani.

\section{K SIE G A TRZECIA}

\section{Dobra kościelne}

Dobra kościeine stanowią własność kościelnych osób moralnych, które zazwyczaj są też uznane przez prawo państwowe. Dobra te są potrzebne nie tylko dla istnienia samych osób moralnych, ale do przeprowadzenia przez nie celów, dla których one istnieją. Osoby moralne mają swoich prokuratorów, którzy występują w ich imieniu

\section{Diecezjalna Rada Administracyjna}

Dla usprawnienia i kontroli zarządu dóbr kościelnych przy Wikariacie zostaje ustanowiona Diecezjalna Rada Administracyjna. Podobne rady mogą powstać przy parafiach, zakony rządzą się swoimi przepisami. Diecezjalna rada składa się $z$ ośmiu członków, między którymi musi być kurialista pelniący tu rolę notariusza oraz dwóch proboszczów, reszta to biegli $w$ tej dziedzinie. Oprócz Rady Diecezjalnej Wikariat ma specjalny referat od spraw gospodarczych, który prowadzi księgi przychodów i rozchodów, inwentarza, lokaty, testamenty, itp. Na referat ten płacą składki:

1. $2^{0} / 0$ czystego dochodu poszczególne beneficja i osoby moralne,

2. $2^{\%} \%$ czystego dochodu parafie i wikarie zakonne,

3. $1^{0 \%}$ sanktuaria i stowarzyszenia związane $z$ różnymi kościolami.

\section{Administratorzy dóbr kościelnych}

Składają przysięgę wiernego wypełniania swoich obowiązków i dołożą troski aby nie tylko utrzymać, ale i powiększyć powierzone sobie dobra. Administrator tak zarządza, aby nie poczynic szkody i strat a większe wydatki uzgodnić z kierownikiem osoby moralnej. Prowadzi odpowiednie księgi a co do alienacji dóbr zachowuje dokładnie przepisy Kodelsu Prawa Kanonicznego, a w miare potrzeby i praẃo państwowe. Starać się też będzie ustrzec dobra kościelne przed ogniem i złodziejami. 
Wszelkie budowy, remonty, przebudowy obiektów sakralnych można dokonywać dopiero po zatwierdzeniu przez Komisję diecezjalną. Podobnie też należy uzyskać zgodę tej Komisji na alienację rzeczy religijnych wartosciowych i artystycznych.

Inwentarze, archiwa i biblioteki należy prowađzić zgodnie z przepisami Prawa Kanonicznego i Ustaw Synodalnych.

Wikariat ustanowi zasady wynagrodzenia księży wikariuszy biorąc pod uwagę lata pracy i ewentualne dochody ich $\mathrm{z}$ uposażenia państwowego lub innych źródel. Tak samo zgodnie z przepisami należy zatroszczyć się o warunki pracy, mieszkania, sprawiedliwego wynagrodzenia, ubezpieczenia, leczenia, gdy zajdzie potrzeba i emerytury wszystkich innych pracowników kościelnych.

Ponieważ beneficja nie są jednakowe i dochody nierówne Wikariat superflua beneficiów bogatszych nakaże przesłać biedniejszym. Wiernych należy zachęcać, by ze swej strony przychodzili z pomoca biednym kościołom i ich duchowieństwu.

Kapłani diecezjalni powinni napisać zgodny z przepisami testament, w którym pomyślą najpierw o duszy wìasnej zostawiając legaty na dobre cele. Pamiętać będą, aby na mocy testamentu szaty lub naczynia kościelne nie były wystawione na sprzedaż lub nie dostały się $\mathrm{w}$ nieodpowiednie ręce. W szczególnie dokładny sposób prowadzić będą książkę $z$ intencjami mszalnymi.

Wszyscy kapłani powinni pomyśleć o chorobach, niezdolności do pracy i starości zgodnie z przepisami władzy kościelnej.

Zarówno poszczégólni administratorzy dóbr kościelnych jak i caly Kościći może ponieść szkody z jakiegoś ṕrzemilczenia lub fałszywego podawania stanu rzeczy, dlatego nie będzie bez pożytku przypomnieć wszystkim o koniecznej uczciwości w wykonywaniu tych odpowiedzialnych obowiązków.

Ks. Bronisław Panek 